\title{
Equality as a Central Principle in the First Amendment
}

\author{
Kenneth L. Karst $\dagger$
}

Freedom of speech is indivisible; unless we protect it for all, we will have it for none.

HaRRY KaLvEN, JR.

The ideal of equality runs deep in the American tradition. ${ }^{1}$ A just society, we believe, must offer "equal liberties"' in the realm of political participation. Within the past generation, this tradition has flowered into a number of new constitutional doctrines, aimed at effectuating the ideal of political equality. ${ }^{3}$ In the aggregate, these doctrines mark the emergence of a principle of equal liberty of expression, not merely in the political arena, but throughout all the interdependent "decisionmaking" processes of a complex society. ${ }^{4}$

A natural doctrinal vehicle for promoting the principle of equal liberty of expression is the guarantee of equal protection of the laws. ${ }^{5}$ In a number of recent cases involving first amendment interests, the

$\dagger$ Professor of Law, University of California, Los Angeles. I am grateful to my colleagues Professors Melville B. Nimmer and Harold W. Horowitz, who commented on a draft of this article.

1 When the ideal of equality was enshrined in the Declaration of Independence, the contrast between ideal and reality was dramatic. Suffrage, for example, was commonly limited in the newly independent states not merely to males but to property owners. See C. Williamson, American Sufrrage: From Property to Democracy, 1760-1860, at 92-116 (1960). And Jefferson, the author of the Declaration's language about equality, owned slaves.

2 See J. Rawls, A TheORY of Justice 205-11 (1971).

3 E.g., Reynolds v. Sims, 377 U.S. 533 (1964) ("one person, one vote"). This application of the principle of equality held little appeal for the Framers of the Constitution. See, e.g., The Federalist No. 10 (1787) (J. Madison).

- Thomas Emerson properly concludes that the principle of freedom of expression:

.. . carries beyond the political realm. It embraces the right to participate in the building of the whole culture, and includes freedom of expression in religion, literature, art, science, and all of the areas of human learning and knowledge.

T. EMerson, The System of Freedom of Expression 7 (1970). Alexander Meiklejohn gives us a curiously narrower view of the same freedoms:

... I believe, as a teacher, that the people do need novels and dramas and paintings and poems "because they will be called upon to vote."

Meiklejohn, The First Amendment is an Absolute, 1961 Sup. Cr. Rev. 245, 263.

5 Throughout this article, the expression "equal protection" includes the right to equality guaranteed against the federal government by the due process clause of the fifth amendment. See, e.g., Bolling v. Sharpe, 347 U.S. 497 (1954). 
Supreme Court has used the framework of equal protection analysis to limit government's power to restrict free expression. ${ }^{6}$ This approach has met with the objection, both within and outside the Court, that the first amendment itself would have been a more appropriate ground for decision. ${ }^{7}$ Framing the problem of free expression in equal protection terms, it is said, misses the basic purpose of the first amendment, which is not equality but liberty. ${ }^{8} \mathrm{By}$ emphasizing the equality principle, the Court may invite government to equalize not by lifting restrictions from some but by suppressing the expression of all. ${ }^{\text {Th }}$ The principle of equality may have its uses in ensuring the freedom of expression, the critics argue, but those uses are marginal to the first amendment's main goals.

This line of argument is misleading. Although the critics' preference for the first amendment as a ground for decision is perfectly sound, their argument gives life to a false assumption about the amendment's meaning. The principle of equality, when understood to mean equal liberty, is not just a peripheral support for the freedom of expression, but rather part of the "central meaning of the First Amendment."10

Although the Supreme Court has only recently recognized the centrality of the equality principle in the first amendment, the principle was implicit in the Supreme Court's "public forum" decisions ${ }^{11}$ as well as in its decisions protecting the associational rights of political minorities. ${ }^{12}$ More fundamentally, the principle of equal liberty lies at the heart of the first amendment's protections against government regulation of the content of speech. Proper appreciation of the importance of the equality principle in the first amendment suggests the need for a reconsideration of the results reached by the Supreme Court in several doctrinal subspheres.

- See, e.g., Police Dep't v. Mosley, 408 U.S. 92 (1972); Williams v. Rhodes, 393 U.S. 23 (1968).

7 See, e.g., Williams v. Rhodes, 393 U.S. 23, 38-40, $41-42$ (1968) (Douglas, J., \& Harlan, J., concurring); Note, Equal But Inadequate Protection: A Look at Mosiey and Grayned, 8 Harv. Civ. Rights-Civ. Lib. L. Rev. 469 (1973).

see, e.g., Rodriguez v. San Antonio Ind. School Dist., 411 U.S. 1, 61 (1973) (Stewart, J., concurring). But of. Van Alstyne, Political Speakers at State Universities: Some Constitutional Considerations, 111 U. PA. L. REv. 328, 338 (1963).

- See Blasi, Prior Restraints on Demonstrations, 68 Mich. L. REv. 1482, 1492-97 (1970); Note, supra note 7, at 476-77.

10 The phrase, "central meaning of the First Amendment," is borrowed from New York Times Co. v. Sullivan, 376 U.S. 254, 273 (1964), by way of Kalven, The New York Times Case: A Note on "The Central Meaning of the First Amendment," 1964 Sup. CT. REv. 191.

"See text and notes at notes 84-110 infra.

12 See text and notes at notes 111-16 infra. 
Just such a reconsideration is the aim of this article. When the equality principle is applied to content regulation, it demands a rethinking of several lines of decision. In the "public forum" area, where the equality principle made its first appearances, a clear understanding of the principle should encourage the Court to abandon inconsistent precedents. The principle of equal liberty of expression also calls for a new look at the problem of access to the communications media. Finally, the first amendment's equality principle implies further constitutional progress toward equalization of the electoral process.

Exploring these doctrinal areas in light of the principle of equal liberty of expression will necessarily raise ancillary questions long familiar in equal protection analysis: the problem of inequalities resulting from hidden or inexplicit "classifications," the relation between formal and substantive equality, the "stopping-place" problem, and analogies to the "state action" limitation. All will be considered as they bear on first amendment determinations. In short, this article explores the consequences for first amendment doctrine of the Supreme Court's adoption of the principle of equal liberty of expression. Before embarking on that exploration, however, we examine the equality principle in relation to the first amendment's main purposes, and we pause to appreciate the Court's first full articulation of the principle in Police Department of the City of Chicago v. Mosley. ${ }^{13}$

It may be, as Paul Freund has remarked, that a memorial occasion like this one normally provides "an even truer insight into the speaker than into the subject."14 Yet Harry Kalven surely would have approved the aims of this analysis, however he might have judged its execution. His writings repeatedly touched on aspects of the equality principle in the first amendment, and my debt to him will be plain to anyone who compares his pages to these. ${ }^{15}$ In any

is 408 U.S. 92 (1972).

" P. Freund, On Understanding the Supreme Court 13 (1951).

15 Ten years ago, I set out to write a review of Kalven's book, THE NEGro and THE First AMENDMENT (1965). The project led me to look back at all of his writings on the first amendment, and the review turned into an article, The First Amendment and Harry Kalven: An Appreciative Comment on the Advantages of Thinking Small, 13 U.C.L.A.L. REv. 1 (1965). It was becoming clear in 1965, and it is quite clear today, that Kalven's contributions to the growth of constitutional law are matched by those of only a handful of people outside the Supreme Court. The present article is still another testimony to the ways in which Kalven has shaped first amendment thinking. It is noteworthy, in an unbelieving age, that Kalven paid attention to doctrine, as something that mattered. His gift to us was a lawyer's gift: careful doctrinal analysis, with doctrine pinned to reality. That he wrote as he talked, bubbling over with humor and intellectual excitement, is a bonus we can still enjoy. 
case, the Freund dictum can be turned to good use. On another memorial occasion, ${ }^{16}$ Harry Kalven wrote in paraphrase of his subject, Justice Black:

Freedom of speech is indivisible; unless we protect it for all, we will have it for none. ${ }^{17}$

\section{Equality and the Purposes of the First Amendment}

The principle of equal liberty of expression underlies important purposes of the first amendment. Three such purposes, not always distinct in practice, are commonly identified:18 (1) to permit informed choices by citizens in a self-governing democracy, (2) to aid in the search for truth, and (3) to permit each person to develop and exercise his or her capacities, thus promoting the sense of individual self-worth. As a practical matter, realization of these goals implies realization of the first amendment's equality principle.

\section{A. Self-government}

It was logical for the Declaration of Independence to link the ideal of political equality with the affirmation that governments derive their just powers from the consent of the governed. Contract theorists from Locke ${ }^{19}$ to Rawls ${ }^{20}$ have drawn a similar connection, giving political content to Luther's doctrine of the priesthood of all believers. If persons are equal, then legitimate government must be based on the consent of the governed. And if equals consent to be governed, rational self-interest dictates that each can preserve his or her own liberty only by agreeing to the equal liberty of all. ${ }^{21}$

"The occasion was Justice Black's thirtieth anniversary on the Supreme Court.

${ }^{17}$ Kalven, Upon Rereading Mr. Justice Black on the First Amendment, 14 U.C.L.A.L. REv. 428, 432 (1967).

18 These purposes are not exhaustive. For example, on another view, the first amendment serves chiefly as a safety valve, permitting peaceful reform within a stable system-or, as Herbert Marcuse would have it, preventing revolution through "repressive tolerance." The function can be seen more positively as one of legitimizing. Chief Justice Warren remarked in the context of a claim of equal protection:

Any unjustified discrimination in determining who may participate in political affairs or in the selection of public officials undermines the legitimacy of representative government.

Kramer v. Union Free School Dist. No. 15, 395 U.S. 621, 626 (1969); cf. C. BLAcK, The People AND THE COURT 34-55 (1960).

" J. Locke, Two Treatises of Government, Book II, ch. VIII, Nos. 95-122 (1690).

20 RawLs, supra note 2.

21 Id. at 207. 
Consent is thus conditioned on the preservation of equality under law. In Rousseau's words,

[T] he social compact establishes among the citizens such an equality that they all pledge themselves under the same conditions and ought all to enjoy the same rights. . . . [T]he sovereign never has a right to burden one subject more than another, because then the matter becomes particular and his power is no longer competent. ${ }^{22}$

The principle invoked by Rousseau is not limited to political rights, but logically extends into the argument advanced by Justice Jackson in his justly celebrated concurrence in Railway Express Agency v. New York:23

There is no more effective practical guaranty against arbitrary and unreasonable government than to require that the principles of law which officials would impose upon a minority must be imposed generally. Conversely, nothing opens the door to arbitrary action so effectively as to allow those officials to pick and choose only a few to whom they will apply legislation and thus to escape the political retribution that might be visited upon them if larger numbers were affected. Courts can take no better measure to assure that laws will be just than to require that laws be equal in operation.

A general theory of equal protection is thus derived from the contract rationale that earlier generated a theory of equal political participation.

Alexander Meiklejohn based his eloquent defense of the freedom of political expression on similar reasoning. In Free Speech and Its Relation to Self-Government, ${ }^{24}$ Meiklejohn argued that a government deriving its legitimacy from the consent of the governed is based upon "a voluntary compact among political equals"'25 and depends for its success on the wisdom of the voters. This wisdom is to be found "only in the minds of [the self-governing community's] individual citizens." ${ }^{26}$ The government, Meiklejohn contended, must not prevent the community from hearing any ideas relevant to their task of self-government:

22 J. Rousseau, The Social Contract, Book II, ch. IV (Tozer transl. 1902), in F. Coker, Readings in Political Philosophy 646-47 (rev. ed. 1938).

${ }^{23} 336$ U.S. 106, 112-13 (1949).

24 A. Meiklejohn, Free Speech and Its Relatton to Self-Government (1948). See also A. Meiklejohn, Political Freedom, The Constitutional Powers of the People (1960).

${ }^{25}$ A. Meiklejohn, Free Speech and Its Relation to Self-Government 11 (1948).

28 Id. at 25. 
Citizens . . . may not be barred [from speaking] because their views are thought to be false or dangerous. . . . And the reason for this equality of status in the field of ideas lies deep in the very foundations of the self-governing process. When [people] govern themselves, it is they-and no one else-who must pass judgment upon unwisdom and unfairness and danger. ${ }^{27}$

Insofar as a guarantee of free speech rests on a theory of selfgovernment, then, the principle of equal liberty of expression is inherent in that guarantee.

\section{B. The Search for Truth}

The suppression of speech necessarily retards society's search for knowledge. The argument on behalf of the need for unfettered speech has been stated most eloquently by John Stuart Mill:

Complete liberty of contradicting and disproving our opinion is the very condition which justifies us in assuming its truth for purposes of action; and on no other terms can a being with human faculties have any rational assurance of being right. ${ }^{28}$

Mill was not only a political philosopher, but also a pioneer of modern social science. His quoted statement reflects the essence of the scientific method: no hypothesis can be taken as proved in the absence of attempts to disprove it. The widest freedom to contradict prevailing opinion is thus implicit in any serious search for truth. ${ }^{29}$ The advancement of knowledge depends on unfettered competition between today's prevailing opinions and those opinions that may come to prevail tomorrow. Preserving competition among ideas demands protecting the expression of all views, including minority views, and all speakers, including unpopular ones.

C. Self-expression and Individual Dignity

The interest in voting is fundamental, it is sometimes said,

${ }^{27}$ Id. at 26.

23 J.S. Mill, ON Liberty (1859), in The Philosophy of John Stuart Mill 207-08 (M. Cohen ed. 1961). Compare Judge Learned Hand's letter to Justice Holmes in 1918, when the first amendment was still lying on the constitutional shelf in its original packaging:

Opinions are at best provisional hypotheses, incompletely tested. The more they are tested, after the tests are well scrutinized, the more assurance we may assume, but they are never absolutes. So we must be tolerant of opposite opinions or varying opinions by the very fact of our incredulity of our own.

Document No. 1 in Gunther, Learned Hand and the Origins of Modern First Amendment Doctrine: Some Fragments of History, 27 Stan. L. REv. 719, 755 (1975).

23 J. Milton, Areopagitica (1644), in Areopagitica and Other Prose Works 1, 38 (1927). 
because it is "preservative of all rights." 30 But irrespective of any tangible benefits to be obtained from government through the ballot, voting remains a crucial symbol of citizenship, of membership in the community. In this sense, racial discrimination in voting inflicted the same harm as denial of service to blacks at lunch counters; both served to degrade and humiliate a racial minority. ${ }^{31}$

Seen in this perspective, the principle of equal liberty of expression serves the same ends as equality in the right to vote. Each is necessary not only for the development of the individual's capacities, but also for the sense of self-respect that comes from being treated as a fully participating citizen.

It is no accident that strains on the system of freedom of expression typically come from the disadvantaged. The boisterous assertiveness of much of the civil rights movement, for example, is traceable not only to a need to use the streets and parks as a "public forum," 32 but more fundamentally to a need for self-assertion simply as a way of staking a claim to equal citizenship. Equality of expression is indispensable to a society committed to the dignity of the individual.

\section{The Crystallization of the Equality Principle}

Although the principle of equal liberty of expression is inherent in the first amendment, it has only recently received full and explicit articulation in an opinion of the Supreme Court. Fleeting pronouncements are to be found in some opinions of a generation ago, ${ }^{33}$ and more recently the principle was the basis of an oft-cited concurring opinion. ${ }^{34}$ But it was not until 1972, in Police Department of the City of Chicago v. Mosely, ${ }^{35}$ that the Court enunciated the principle fully. In Mosley, a man who had been picketing peacefully near a school, carrying a sign protesting "black discrimination," sought to enjoin enforcement of a new city ordinance prohibiting picketing within 150 feet of a school during school hours; he

${ }^{30}$ Reynolds v. Sims, 377 U.S. 533, 562 (1964), quoting Yick Wo v. Hopkins, 118 U.S. 356, 370 (1886).

${ }^{31}$ See generally Black, The Lawfulness of the Segregation Decisions, 69 YALE L.J. 421 (1960); C. Woodward, The Strange Career of Jim Crow (2d rev. ed. 1966). In Brown v. Board of Educ., 347 U.S. 483 (1954), the Court placed great emphasis on the indignity felt by black children who were forced to attend segregated schools. Id. at 494.

32 See text and notes at notes 84-110 infra.

as See, e.g., Fowler v. Rhode Island, 345 U.S. 67 (1953); Niemotko v. Maryland, 340 U.S. 268,272 (1951).

${ }^{3}$ Cox v. Louisiana, 379 U.S. 536, 581 (1965) (Black, J., concurring).

35408 U.S. 92 (1972). 
had been advised by the police that he would be arrested if he continued to picket. The ordinance contained an exception for "peaceful picketing of any school involved in a labor dispute." The Seventh Circuit held the ordinance invalid as an overly broad restriction of first amendment rights. ${ }^{36}$ The Supreme Court affirmed but rested its decision on the ground that the ordinance violated the fourteenth amendment's guarantee of equal protection of the laws. ${ }^{37}$

Mosley squarely addresses the relationship between the equality principle and the first amendment. Despite the Court's choice of an equal protection ground for decision, its opinion speaks chiefly to first amendment values and primarily cites first amendment cases as authority. In discussing the question of equal opportunity to be heard, Justice Marshall, writing for the Court, observes that the main problem with the ordinance

is that it describes permissible picketing in terms of its subject matter. . . . [A]bove all else, the First Amendment means that government has no power to restrict expression because of its message, its ideas, its subject matter, or its content. . . . To permit the continued building of our politics and culture, and to assure self-fulfillment for each individual, our people are guaranteed the right to express any thought, free from government censorship. The essence of the forbidden censorship is content control. ...

Necessarily, then, under the Equal Protection Clause, not to mention the First Amendment itself, government may not grant the use of a forum to people whose views it finds acceptable, but deny use to those wishing to express less favored or more controversial views. And it may not select which issues are worth discussing or debating in public facilities. There is an "equality of status in the field of ideas" [quoting Meikle$\left.\mathrm{john}^{38}\right]$ and government must afford all points of view an equal opportunity to be heard..$^{39}$

Justice Marshall then discusses the level of judicial scrutiny to be applied when first amendment interests are adversely affected by an unequal opportunity to be heard:

36 Mosley v. Police Dep't, 432 F.2d 1256 (7th Cir. 1970).

${ }^{37}$ The Court reached a similar conclusion in Grayned v. City of Rockford, 408 U.S. 104 (1972), decided the same day as Mosley. The Grayned opinion merely cites Mosley, and holds a similar ordinance invalid on equal protection grounds, without mentioning the first amendment.

33 See A. MeikLejoHn note 25 supra, at 11.

39 408 U.S. at $95-96$. 
We have continually recognized that reasonable "time, place and manner" regulations of picketing may be necessary to further significant governmental interests. ${ }^{40}$. . . Similarly, under an equal protection analysis, there may be sufficient regulatory interests justifying selective exclusions or distinctions among pickets. . . . But these justifications for selective exclusions from a public forum must be carefully scrutinized. Because picketing plainly involves expressive conduct within the protection of the First Amendment . . . discriminations among pickets must be tailored to serve a substantial governmental interest. ... .

In this case, the ordinance itself describes impermissible picketing not in terms of time, place, and manner, but in terms of subject matter. The regulation "thus slip[s] from the neutrality of time, place and circumstances into a concern about content" [quoting Kalven ${ }^{41}$ ]. This is never permitted. ${ }^{42}$

Largely ignored by the law reviews ${ }^{43}$ Mosley is a landmark first amendment decision. It makes two principal points: (1) the essence of the first amendment is its denial to government of the power to determine which messages shall be heard and which suppressed; "government must afford all points of view an equal opportunity to be heard." (2) Any "time, place and manner" restriction that selectively excludes speakers from a public forum must survive careful judicial scrutiny to ensure that the exclusion is the minimum necessary to further a significant government interest. Taken together, these statements declare a principle of major importance. The Court has explicitly adopted the principle of equal liberty of expression.

Adherence to the principle of equal liberty of expression will have far-reaching implications even though absolute equality is a practical impossibility. The principle requires courts to start from the assumption that all speakers and all points of view are entitled to a hearing, and permits deviation from this basic assumption only upon a showing of substantial necessity. The emergence of the equality principle compels a critical re-examination of several lines

to Citing, inter alia, Cox v. Louisiana, 379 U.S. 536, 559 (1965).

"Kalven, The Concept of the Public Forum: Cox v. Louisiana, 1965 Sup. CT. Rev. 1, 29.

12408 U.S. at $98-99$.

${ }^{43}$ Apart from the student note cited in note 7 supra, the only contemporaneous reference I have found is in 58 A.B.A.J. 1099 (1972). Mosley, however, is now routinely cited by the Justices and the lower courts. See text at note 241 infra. 
of first amendment decisions. We begin at the heart of the first amendment, with its prohibition on censorship of speech content.

\section{The Equality Principle and Content Discrimination}

The absence of a clear articulation of the principle of equal liberty of expression in Supreme Court decisions before Mosley may be attributable to a belief that the principle is so obviously central among first amendment values that it requires no explanation. In $S c h a c h t v$. United States, ${ }^{44}$ for example, a participant in an antiwar skit was prosecuted under a statute that prohibited wearing an Army uniform without authorization. The statute contained an exception allowing the uniform to be worn in a theatrical performance "if the portrayal does not tend to discredit" the armed forces. Justice Black, speaking for the Court, found it unnecessary to cite any authority or offer any explanation for holding that the statutory exception, "which leaves Americans free to praise the war in Vietnam but can send persons like Schacht to prison for opposing it, cannot survive in a country which has the First Amendment." 45 There is a sense in which we have always known that "unless we protect [freedom of speech] for all, we will have it for none."46

The equality principle, viewed as a barrier against content censorship, also implicitly underlies the elaborate first amendment doctrines that prohibit giving officials discretion to decide when speech shall be permitted and when it shall be punished or the speaker denied a license. The danger of delegating such discretion-

4398 U.S. 58 (1970).

is 398 U.S. at 63; cf. Tinker v. Des Moines School Dist., 393 U.S. 503 (1969), in which the school board had tolerated the wearing of other political symbols, but had forbidden students to wear black armbands to protest the Vietnam war. The restriction was held to be an unconstitutional content discrimination. But cf. United States v. O'Brien, 391 U.S. 367 (1968), where the Court seemed unable to view a statute that prohibited the burning of draft cards to be a content discrimination, expressly aimed at suppressing a particular statement-although the First Circuit had seen the point clearly. Perhaps O'Brien could have been convicted constitutionally for burning his draft card. See Ely, Flag Desecration: A Case Study in the Roles of Categorization and Balancing in First Amendment Analysis, 88 HARv. L. REv. $1482,1496-1500$ (1975). But that fact does not excuse the Court from failing to come to grips with the issue of content discrimination. See Nimmer, The Meaning of Symbolic Speech Under the First Amendment, 21 U.C.L.A.L. REv. 29, 38-42 (1973). Nimmer's discussion of "overnarrow" legislation is an illuminating application of the first amendment's equality principle in its most important dimension, as a prohibition on content discrimination.

"Kalven, supra note 17. In order to uphold the constitutionality of the rest of the statute, the Court struck the words "if the portrayal does not tend to discredit" from the actor's exception. 398 U.S. at 63. 
ary authority is that a vague licensing ${ }^{47}$ or criminal statute ${ }^{48}$ would enable the prosecutor or censor to enforce the law selectively, tolerating orthodox views while suppressing unpopular ones. ${ }^{49}$ The same concern underlies decisions imposing rigorous limits on the seizure of obscene literature. ${ }^{50}$ It is not accidental that these first amendment doctrines serve equality not only at the level of principle but also at a practical level, defending nonconformists, dissenters, and the disadvantaged. ${ }^{51}$ The principle of equal liberty of expression, like the equal protection clause, has special relevance for protecting the downtrodden.

Given the centrality of the equality principle as a protection against content censorship, it seems likely that the Supreme Court will eventually complete the job of dismantling what Harry Kalven termed the "two-level" theory of speech. ${ }^{52}$ According to this theory, which sprang from an unguarded dictum in Chaplinsky $v$. New Hampshire, ${ }^{53}$ certain kinds of speech content, such as obscenity, libel, or "fighting words," lie outside the protection of the first amendment and may be banned without judicial scrutiny of the state's justification. Kalven destroyed the intellectual foundations of the two-level theory as early as 1960, in his classic analysis of the law of obscenity. ${ }^{54} \mathrm{He}$ argued that the two-level theory not only begged the crucial question of formulating a constitutional test for obscenity, but made judicial categorization dispositive without defining the categories adequately. More importantly, he observed that the two-level theory, by reading obscenity out of the first amendment because it lacks "redeeming social importance," vio-

${ }^{47}$ See, e.g., Shuttlesworth v. City of Birmingham, 394 U.S. 147 (1969); Joseph Burstyn, Inc. v. Wilson, 343 U.S. 495 (1952).

${ }^{13}$ See, e.g., Winters v. New York, 333 U.S. 507 (1948).

4 A similar concern is surely reflected in decisions like Cox v. Louisiana, 379 U.S. 536 (1965) and Edwards v. South Carolina, 372 U.S. 229 (1963), insofar as they involve the "hostile audience" problem. If the duty of the police in such a situation is to protect the speaker as long as they can, part of the reason must be to avoid letting the police decide to stop the speaker because of disagreement with his or her views. Feiner v. New York, 340 U.S. 315 (1951), decided the same day as Niemotko v. Maryland, 340 U.S. 268 (1951), is curiously insensitive to this concern. Cf. Gregory v. Chicago, 394 U.S. 111, 120 (1969) (Black, J., concurring): "[U]nder our democratic system of government, lawmaking is not entrusted to the moment-to-moment judgment of the policeman on his beat."

${ }^{50}$ E.g., Roaden v. Kentucky, 413 U.S. 496 (1973).

${ }^{51}$ Cf. Papachristou v. Jacksonville, 405 U.S. 156, 170 (1972) (vague vagrancy ordinance especially dangerous because of the likelihood of selective enforcement against "poor people, nonconformists, dissenters, idlers").

${ }^{52}$ Kalven, The Metaphysics of the Law of Obscenity, 1960 SuP. CT. REv. 1, 10.

53315 U.S. 568, 571-72 (1942).

st Kalven, supra note 52, at 19. 
lates the first amendment principle that prohibits weighing the social utility of speech.

The two-level theory is radically inconsistent with the principle of equal liberty of expression. While the equality principle in the first amendment does not prohibit all content regulation, it does require that courts start with a presumptive prohibition against governmental control of the content of speech. A showing of high probability of serious harm might justify regulation of a particular kind of speech content, but the two-level theory evades the question of justification by placing certain types of speech outside the scope of the first amendment. In other words, the two-level theory rejects the principle of equality in the marketplace of ideas. ${ }^{55}$

In the field of defamation, the Court has already gone far toward abandoning the two-level theory. No one would suggest that New York Times Co. v. Sullivan ${ }^{56}$ and its diverse offspring ${ }^{57}$ leave libel outside the boundaries of protected speech. ${ }^{58}$ And even the "fighting words" cases have fought their way out of the confines of the two-level theory, coming to rest on a variety of the clear-andpresent-danger test. ${ }^{59}$ But loyalty to the two-level theory is curiously persistent. Chief Justice Burger surely had the two-level theory in mind when he added a brief concurring opinion in Mosley, expressing his reservations about the sweep of the Court's adoption of the principle of equal liberty of expression:

Numerous holdings of this Court attest to the fact that the First Amendment does not literally mean that we "are guaran-

ss The debate between "balancers" and "categorizers" is a long, long tunnel, without apparent end. See, e.g., Ely, supra note 45, at 1500-02. Kalven's discussion of the two-level theory, supra note 52, was and remains a salutary reminder of the dangers that the first amendment can be "categorized away" as well as "balanced away."

st 376 U.S. 254 (1964); see Kalven, supra note 10.

${ }^{37}$ E.g., the law of privacy; see Time, Inc. v. Hill, 385 U.S. 374 (1967); Nimmer, The Right to Speak from Times to Time: First Amendment Theory Applied to Libel \& Misapplied to Privacy, 56 Cal.r. L. Rev. 935 (1968); and libel of "public figures," Curtis Publishing Co. v. Butts, 388 U.S. 130 (1967), and persons swept up in matters of public interest, Gertz v. Robert Welch, Inc., 418 U.S. 323 (1974).

ss There may remain a last ditch for the two-level theory in the case of the "purely private" libel of this general style: "Lady Cynthia should not marry Cadwallader; in India he cheated at cards." And even where the New York Times rule applies, it is still possible to say that libel published with knowledge or reckless disregard of its falsity is beneath the concern of the first amendment. To put the matter this way is to show how far the Court has gone in bringing libel back into the amendment's shelter.

so See, e.g., Gooding v. Wilson, 405 U.S. 518 (1972); cf. Lewis v. New Orleans, 408 U.S. 913 (1972) (Powell, J., concurring). The Court continues to use the two-level language, but has limited the reach of the "fighting words" exception to cases in which both the statute and the defendant's conduct pass the test of a "direct tendency" to cause violence. 
teed the right to express any thought, free from government censorship." This statement is subject to some qualifications, as for example those of Roth $v$. United States [obscenity], ... [and] Chaplinsky $v$. New Hampshire [fighting words] .... See also New York Times Co. v. Sullivan [wilfully or recklessly false libel] . . . .60

The Chief Justice recognized a crucial truth: the two-level theory cannot survive rigorous application of the first amendment's equality principle.

In the obscenity cases, the Court continues to say that "obscene material is unprotected by the First Amendment." ${ }^{11}$ Yet even in these cases the two-level theory is weakening. Justice Brennan, who fostered this child of the two-level theory, has now abandoned it. ${ }^{.2}$ Furthermore, despite the Court's effort to decentralize the critical decision of what is "obscene material" by deferring to the local community-i.e., the jury ${ }^{63}$ - the Court itself must continue to police at least the borderland of obscenity. Thus, the impact of the two-level theory will be deflected. Not only will speech determined by the jury to be nonobscene be constitutionally protected, but certain speech that is obscene in the jury's view will be brought within the scope of the first amendment's protection. Even if many local. decisions are effectively final, surely some prosecutor will go after the movie, "Carnal Knowledge," some jury will find it obscene, and the Court will feel compelled to intervene in order to protect the film. ${ }^{64}$

In the long run the Court seems likely, in defining obscenity, to return to the guidelines it was beginning to develop before 1973 for justifying censorship: concern over the exposure of children or unwilling "captive audiences" to explicit sex-related material and concern over the commercial exploitation of sexual anxieties. ${ }^{65}$ Speech that is "obscene" will not be banished from all first amendment shelter, but will be subject to restriction upon a showing of serious harmful effects. The two-level theory is alive in the obscenity area, but it is not well.

so 408 U.S. at 103.

" Miller v. California, 413 U.S. 15, 23 (1973).

62 Paris Adult Theatre I v. Slaton, 413 U.S. 49, 83-93 (1973) (dissenting opinion).

${ }^{63}$ Miller v. California, 413 U.S. 15, 26 (1973).

o4 Jenkins v. Georgia, 418 U.S. 153 (1974). The Court relied upon the procedural requirements of Freedman v. Maryland, 380 U.S. 51 (1965), in order to avoid a similar rule as to the possible obscenity of the musical "Hair." In so doing it made some welcome new law on the constitutional limits on a city in its role as proprietor of an auditorium. See text at note 82 infra; Southeastern Promotions, Ltd. v. Conrad, 420 U.S. 546 (1975).

${ }^{65}$ See Stanley v. Georgia, 394 U.S. 557 (1969); Redrup v. New York, 386 U.S. 767 (1967). 
One last area where an offspring of the two-level theory survived longer than it deserved is the area of advertising and "commercial speech." ${ }^{66}$ Valentine $v$. Chrestensen ${ }^{67}$ seemed to place commercial speech in general beyond constitutional protection. Despite occasional murmurs of discontent with such a categorical exclusion, ${ }^{68}$ the shadow of that decision darkened a corner of the first amendment until very recently. ${ }^{69}$

Just last term, however, in Bigelow $v$. Virginia, ${ }^{70}$ the Court invalidated a Virginia law that prohibited any advertisement encouraging the procuring of an abortion. The advertisement in question told Virginia readers how to obtain an abortion in New York and thus proposed the sale of a service. But that fact alone was held insufficient to remove the advertisement from the protection of the first amendment. ${ }^{71}$ Bigelow confined the unfortunate decision in Pittsburgh Press Co. v. Pittsburgh Commission on Human Relations ${ }^{72}$ two years ago, to cases in which advertisements propose unlawful commercial transactions. Most important, the Court expressly laid to rest the notion that Chrestensen created a new branch of the two-level theory for commercial speech or advertising. The abortion advertisement, said the Court,

did more than simply propose a commercial transaction. It contained factual material of clear "public interest."73

"This subject was a blind spot for Alexander Meiklejohn, who was perfectly willing to read the whole area out of the first amendment, including broadcasting, which he saw as "not engaged in the task of enlarging and enriching human communication," but rather as "engaged in making money." A. MEIKLEJOHN, supra note 25, at 104.

$" 316$ U.S. 52 (1942).

"8specially in the lower courts. See generally Redish, The First Amendment in the Marketplace: Commercial Speech and the Values of Free Expression, 39 GEO. WASH. L. REv. 429, 448-72 (1971). See also Developments in the Law-Deceptive Advertising, 80 HaRv. L. Rev. 1005, 1027-38 (1967); Note, Freedom of Expression in a Commercial Context, 78 Harv. L. REv. 1191 (1965).

" E.g., Pittsburgh Press Co. v. Pittsburgh Comm'n on Human Relations, 413 U.S. 376, 384-85 (1973); Cammarano v. United States, 358 U.S. 498, 513-15 (1959) (Douglas, J., concurring).

95 S. Ct. 2222 (1975).

$"$ Since the advertisement did not encourage the procurement of abortions that were then illegal in Virginia, it could not have been suppressed under Brandenburg v. Ohio, 395 U.S. 444 (1969).

72413 U.S. 376 (1973). In Pittsburgh Press, a bare majority of the Court relied on Chrestensen to reject a first amendment attack on an ordinance that had been construed to forbid newspapers from carrying help-wanted advertisements in sex-designated columns except where based upon a bona fide occcupational qualification.

7395 S. Ct. 2222, 2232 (1975). See also Population Services Int'l v. Wilson, 398 F. Supp. 321, 336-39 (S.D.N.Y. 1975) (statute banning advertisement of contraceptive products is invalid). 
Thus the Court turned to the particulars of the speech before it and to the alleged justifications for suppression-justifications that could scarcely survive Roe $v$. Wade. ${ }^{74}$ In other contexts, this analysis would be called "strict scrutiny," and any scrutiny of justifications is inconsistent with the theory that a category of speech lies completely outside the first amendment's boundaries. ${ }^{75}$

Unfortunately, a doctrinal offshoot of the two-level theory in commercial speech cases has recently taken root. In Lehman v. City of Shaker Heights, ${ }^{76}$ the Court upheld, by a 4-1-4 vote, a city transit system's rule that allowed commercial advertising in its cars but forbade political advertising. As the four dissenting Justices naturally thought, the case was a perfect occasion for applying the Mosley principle of equality, since the only distinction between permitted and forbidden advertising turned on the advertising's content. ${ }^{77}$ The three Justices who joined in Justice Blackmun's plurality opinion, however, contrived to ignore the first amendment's equality principle altogether by reasoning that the city was not operating a public forum but was "engaged in commerce." Its decision to exclude political advertising was therefore perceived to be "little different from deciding to impose a 10-, 25-, or 35-cent fare, or from changing schedules or the location of bus stops." ${ }^{79}$ Requiring the city to accept political advertising, said Justice Blackmun, would mean not only that transit riders "would be subjected to the blare of political propaganda," but also that "display cases in public hospitals, libraries, office buildings, military compounds, and other public facilities immediately would become Hyde Parks open to every would-be pamphleteer and politician."80

710 U.S. 113 (1973).

${ }^{25}$ To say that the first amendment applies to commercial speech is not to deny the validity of the regulation of false advertising. See Developments in the Law-Deceptive Advertising, supra note 68. But an awareness of first amendment values in such cases is an improvement over uncritical acceptance of a two-level theory in this area. For an expression of such first amendment concerns, see Chief Judge Fairchild's concurring opinion in FTC v. National Comm'n on Egg Nutrition, 517 F.2d 485, 490 (7th Cir. 1975). See also Terry v. California State Bd. of Pharmacy, 395 F. Supp. 94 (N.D. Cal. 1975), holding invalid state statutes prohibiting the advertising of retail prices of prescription drugs and forbidding any representation that such a drug is sold at a discount price. For a rather more restrictive view of the first amendment values in advertising cases, see Kozyris, Advertising Intrusion: Assault on the Senses, Trespass on the Mind-A Remedy Through Separation, 36 OHо ST. L.J. 299, 308-13 (1975). This article was written before the Bigelow decision.

${ }^{76} 418$ U.S. 298 (1974).

${ }^{77}$ Id. at 315-22 (Brennan, J., dissenting).

${ }^{78} \mathrm{Id}$. at 303.

7d. at 304 .

${ }^{\text {so }}$ Id. at 305-08. Justice Douglas, whose concurrence was necessary to create a majority, relied almost entirely on the argument that bus riders are a captive audience. 418 U.S. at 
This closing rhetoric about hospital display cases and the like utterly misses the point of the dissent's content-discrimination argument. It assumes that the only question is whether there is a constitutional right to use a bus as a public political forum. ${ }^{81}$ Bus riders will be barraged by unwanted advertisements in any case, but neither the plurality nor Justice Douglas ever explained why a political barrage is more offensive than a commercial one. This failure to consider the first amendment's equality principle is particularly inexcusable in view of the dissent's careful development of the theme. Worse, the comparison between forbidding political advertising and setting bus fares forebodes the development of yet another branch of the discredited two-level theory. It suggests that the city should be treated in its proprietary role as largely beyond the reach of the first amendment-a position the Court wisely rejected less than a year later, in Southeastern Promotions, Ltd. v. Conrad ${ }^{82}$ In short, the plurality opinion in Lehman fails the test of craftsmanship as well as the test of good sense, offering instead an idea whose time has come and gone.

Just as the prohibition of government-imposed discrimination on the basis of race is central to equal protection analysis, protection against governmental discrimination on the basis of speech content is central among first amendment values. Equal protection analysis has long understood that governmental action may be neutral on its face and yet have unequal impacts. Similarly, regulations that are formally neutral as to speech content may produce the effect of content discrimination..$^{83}$ Such regulations will be analyzed in light of the first amendment's principle of equal liberty of expression.

\section{Hidden Inequalities: Of Public Forums and Private HARASSMENT}

It was Harry Kalven who coined the term "public forum," now a commonplace of first amendment discourse. Ten years ago, in

306-08. Unless the riders are contortionists, it is hard to see how this argument applies to ads carried on the outside of the buses.

s1 Justice Douglas makes the same assumption in his concurring opinion. Even if the content-discrimination issue were eliminated from Lehman, the majority's treatment of the public forum issue was inadequate. See Stone, Fora Americana: Speech in Public Places, 1974 Sup. CT. Rev. 233, 256-61, 278-80; Note, The Public Forum: Minimum Access, Equal Access, and the First Amendment, 28 Stan. L. Rev. 117 (1975).

82420 U.S. 546 (1975). The Conrad opinion was written by Justice Blackmun, who did not advert to his opinion in Lehman except to note in passing that there was no captive audience problem when patrons chose to go to a municipal auditorium to see "Hair."

* See also note 45 supra (the discussion of United States v. O'Brien, 391 U.S. 367 (1968)). 
analyzing Cox $v$. Louisiana, ${ }^{84}$ he offered the first full articulation of the theory of the public forum. It is fitting to let him introduce the theory in his own words:

[1]n an open democratic society the streets, the parks, and other public places are an important facility for public discussion and political process. They are in brief a public forum that the citizen can commandeer; the generosity and empathy with which such facilities are made available is an index of freedom. ... [W] [Wat is required is in effect a set of Robert's Rules of Order for the new uses of the public forum, albeit the designing of such rules poses a problem of formidable practical difficulty..$^{85}$

All would agree that government can place reasonable and contentneutral restrictions on the time, place and manner of a citizen's commandeering of the public forum. What made Mosley and Lehman easy cases-the outrage of Lehman being that it was an easy case, wrongly decided-was that in restricting the use of picketing and bus advertising the cities did not merely regulate the time, place or manner of speech, but imposed discriminatory controls over the content of speech.

Regulations of the public forum often collide with the equality principle, viewed as a protection against discrimination based on speech content. Many of the licensing decisions aimed at avoiding discriminatory content censorship arose in the public forum context. $^{86}$ Indeed, one of the Supreme Court's earliest allusions to the first amendment equality principle came in a park-licensing case, Niemotko $v$. Maryland, ${ }^{87}$ in which the practice of dispensing public park meeting permits on the basis of the religious beliefs of the applicants was held unconstitutional. Public forum cases implicitly rely on the equality principle to protect against what might be called de jure content discrimination.

But the public forum cases also touch the equality principle in two other related ways. First, even a formally content-neutral time, place and manner restriction may have unequal effects on various types of messages. The resulting inequality may be constitutionally unacceptable, whether or not the discrimination is intended. Sec-

s4 379 U.S. 536 (1965).

ss Kalven, supra note 41 , at 11-12. See also H. Kalven, The Negro and the First AMENDMENT 123-60 (1965).

ss E.g., Shuttlesworth v. City of Birmingham, 394 U.S. 147 (1969); Kunz v. New York, 340 U.S. 290 (1951); Lovell v. City of Griffin, 303 U.S. 444 (1938).

${ }^{87} 340$ U.S. 268 (1951). 
ond, the very concept of the public forum is based in large part on the first amendment equality principle's central concern with avoiding content censorship.

Suppose, for example, that the ordinance in Mosley had not contained the labor-picketing exception, but had banned all picketing within 150 feet of a school during school hours in order to avoid disruption of the school. The burden of this restriction would fall most heavily on those who have something to communicate to the school population of students, faculty and staff. Student picketers presenting a grievance against a principal, or striking custodians with a message growing out of a labor dispute, would be affected more seriously by this ostensibly content-neutral ordinance than would, say, the proponents of a candidate for Governor. The latter might spend their time just as effectively by carrying their signs and message to any similarly populous area, while the students or custodians will find it hard to transmit their messages to their intended audience if they cannot picket near the school. This differential impact amounts to de facto content discrimination, presumptively invalid under the first amendment's equality principle. ${ }^{88}$

City council members are thus presented with an apparent dilemma. ${ }^{89}$ If a city bars all picketing within a certain area, it will effectively discriminate against those groups that can communicate to their audience only by picketing within that area. But if the city adjusts its ordinance to this differential impact, as by providing a student-picketing or labor-picketing exemption, it discriminates between the messages of different groups on the basis of content.

s In this dimension, the first amendment's equality principle may be more far-reaching than the equal protection clause in its present application to de facto racial discrimination. At the moment, the Supreme Court is divided over the question of the presumptive invalidity of legislation having racially discriminatory effects. The issue was avoided in Keyes v. School Dist., 413 U.S. 189 (1973), where the Court found deliberate official action to maintain school segregation in Denver. In one view, of course, there is no "discrimination" in racial imbalance alone, absent intentional action to cause it. A more extreme position is that in Justice Rehnquist's opinion for the Court in Jefferson v. Hackney, 406 U.S. 535 (1972), rejecting the argument that a state welfare scheme was invalid because of its racially discriminatory results. In the long run, the odds are that the Court will adopt the view of Justice Powell, concurring in Keyes, 413 U.S. at 217, that the de facto-de jure distinction should be abandoned in favor of a rule requiring justification for official action that has racially discriminatory effects.

31 The dilemma is analogous to that faced by courts in accommodating the competing demands of the first amendment's two religion clauses. See, e.g., Sherbert v. Verner, 374 U.S. 398 (1963), which posed the question: is South Carolina constitutionally forbidden by the establishment clause to allow an exception for Seventh Day Adventists in administering its unemployment compensation scheme, or is it constitutionally required by the free exercise clause to do so? (Answer: the latter). 
Such an ordinance would run afoul of Mosley itself. The city can avoid the dilemma by amending the ordinance to ban not all picketing but only noisy picketing. ${ }^{90}$

Another problem raised by the hypothetical ordinance banning all picketing is that it is unconstitutionally overbroad; it is not narrowly tailored to the compelling state interest in permitting school activities to go on without interruption. The doctrine of overbreadth frequently serves the purposes of the first amendment's equality principle. One of the evils of an overly broad statute is its potential for selective enforcement. ${ }^{91}$ Police who look charitably on a postgame victory celebration in the streets of a college town may not feel the same way about an antiwar demonstration. Similarly, statutes proscribing abusive words are applied to members of racial and political minorities more frequently than can be wholly explained by any special proclivity of those people to speak abusively ${ }^{92}$ Although vigorous application of the overbreadth doctrine cannot eliminate the danger of selective enforcement, it can minimize the danger by restricting the occasions for enforcement.

More typically, however, the overbreadth doctrine will be used in tandem with the first amendment equality principle. The equality principle can be employed first, to give Justice Jackson's Railway Express theory ${ }^{93}$ a chance to operate. If eliminating exceptions and making the law apply generally should result in increasing the total restriction on speech, ${ }^{94}$ the overbreadth principle can be used as a countervailing force. As in the hypothetical case of the ordinance that was amended to ban all picketing in order to cure the taint caused by the labor-picketing exceptions, ${ }^{95}$ the resulting "dilemma" will force the legislature to draft a law that is, in equal protection terms, neither underinclusive nor overinclusive. ${ }^{96}$ The

90 Such an ordinance was upheld in Grayned v. City of Rockford, 408 U.S. 104 (1972), the companion case to Mosley. As Grayned shows, this type of ordinance is apt to present a vagueness problem, too.

${ }^{91}$ See Note, The First Amendment Overbreadth Doctrine, 83 HaRv. L. Rev. 844, 857 n.55 (1970).

${ }^{22}$ See, e.g., the trio of per curiam decisions, Rosenfeld v. New Jersey, 408 U.S. 901 (1972); Lewis v. New Orleans, 408 U.S. 913 (1972); and Brown v. Oklahoma, 408 U.S. 914 (1972); cf. Cohen v. California, 403 U.S. 15 (1971), in which the offending epithet was addressed to the draft.

${ }^{93} 336$ U.S. 106, 112-13 (1949) (Jackson, J., concurring).

$"$ This was just what happened in the City of Rockford; after Grayned was arrested and convicted, the labor-picketing exception was repealed. 408 U.S. at 107 n.2.

is See text at note 89 supra.

96 See Tussman and tenBroek, The Equal Protection of the Laws, 37 CaLrr. L. Rev. 341, 344-48 (1949). In Erznoznik v. City of Jacksonville, 95 S. Ct. 2268 (1975), a first amendment case discussed in the text at note 236 infra, Justice Douglas, concurring, said, "I join whole- 
equality principle guards against the unequal treatment resulting from underinclusion; the overbreadth principle guards against the hidden inequalities and selective enforcement resulting from overinclusion.

The remedy for a time, place and manner regulation that has a selectively harsh impact on a particular group or message, therefore, is not necessarily the direct application of the equality principle. ${ }^{97}$ But a showing that a formally neutral law has discriminatory effect deserves great weight in persuading a court to look closely at the necessity for the regulation-in other words, to apply the overbreadth principle rigorously. ${ }^{98}$ As in the case of a law banning all picketing near a school, the disproportionate burden borne by striking school employees may not be necessary to achieve the state's purpose of preventing disruptions in school; a law banning noisy picketing is more closely tailored to that goal.

Furthermore, the equality principle cautions us not to take the notion of a Robert's Rule of Order too literally as a measure of permissible restriction of the public forum. The formal equality of "content-neutral" procedural rules, like that of the statute banning all picketing, may conceal a hidden inequality. The difficulty in analogizing the public forum to a parliamentary forum escaped even Alexander Meiklejohn:

The First Amendment . . . is not the guardian of unregulated talkativeness. It does not require that, on every occasion, every citizen shall take part in public debate. Nor can it even give assurance that everyone shall have opportunity to do so. If, for example, at a town meeting, twenty like-minded citizens have become a "party," and if one of them has read to the meeting an argument which they have all approved, it would be ludicrously out of order for each of the others to insist on reading it again. No competent moderator would tolerate that wasting of the time available for free discussion. What is essential is not that everyone shall speak, but that everything worth saying shall be said.9

heartedly in the Court's view that the ordinance in issue here is fatally overinclusive in some respects and fatally underinclusive in others."

"But see the political privacy cases discussed in the text at note 111 infra.

18 The Court has implied that the overbreadth doctrine retains its full vigor, even after the dilution implicit in the term "substantial overbreadth," in a case involving "a censorial statute, directed at particular groups or viewpoints." Broadrick v. Oklahoma, 413 U.S. 601, 616 (1973).

" A. Meiklejohn, supra note 25, at 25. 
Meiklejohn's rather strained example does not even typify the expression in town meetings, let alone the sort of freewheeling expression characteristic of debate in the public forum. But Meiklejohn is wrong in a more fundamental way. The state lacks "moderators" who can be trusted to know when "everything worth saying" has been said, and the legislature lacks the capacity to write laws that will tell a moderator when to make such a ruling. And even the repetition of speech conveys the distinctive message that an opinion is widely shared. The impression of a mounting consensus is of great importance in an "other-directed" society 100 where opinion polls are self-fulfilling prophecies. A vital public forum requires a principle of equal liberty of expression that is broad, protecting speakers as well as ideas.

A city council bent on squelching the expression of minority views could, of course, attempt to achieve its aim by "distinguishing not between users but between uses." 101 The council might, for example, pass a law banning all picketing. The chief criticism of the Court's reliance on the equality principle in Mosley was that the city arguably could equalize speech through wholesale restriction. ${ }^{102}$ But the first amendment equality principle itself underlies the public forum concept. Limitations on the modes of expression in the public forum-hidden discrimination-may undermine that principle and thus subvert the notion of a truly public forum. Harry Kalven summarized the point gracefully:

In the Jehovah's Witness cases, the Court had been outspokenly sensitive to the "poor man's printing press" 103 theme. Labor picketing apart, perhaps, the parade, the picket, the leaflet, the sound truck, have been the media of communication exploited by those with little access to the more genteel means of communication. We would do well to avoid the occasion for any new epigrams about the majestic equality of the law prohibiting the rich man, too, from distributing leaflets or picketing. ${ }^{104}$

Even assuming the correctness of Meiklejohn's limited view of the equality principle-that what is important is "that everything

100 See D. Riesman, N. Glazer \& R. Denney, The Lonely Crowd 23 passim (1950).

101 T. EMErson, supra note 4, at 304.

102 Note, supra note 7, at 476-77.

${ }^{103}$ The reference is to Justice Black's opinion for the Court in Martin v. Struthers, 319 U.S. 141, 146 (1943), a case involving distribution of door-to-door circulars, in which he called such activity "essential to the poorly financed causes of little people."

104 Kalven, supra note 41 , at 30 (footnote omitted). 
worth saying shall be said"105_it must be recognized that the content of the messages carried by leafleters and pickets is apt to differ significantly from the content of the daily press and the broadcast media. Thus the equality principle itself requires the most generous definition of the boundaries of the public forum in order to ensure that all will be heard. Concededly, the city has a compelling interest in protecting school activity from material disruption. ${ }^{108}$ But if it seeks to attain this end by means that diminish the area of the public forum, as by restricting picketing near a school, it must show that those means are necessary to achieve that compelling interest. A general ban on picketing will not survive such a test.

Content discrimination, whether overt or hidden, also must not be allowed to infect the definition of the limits of the public forum. The shopping-center cases are an unhappy example of just such a violation of the equality principle. In Lloyd Corp. $v$. Tanner, ${ }^{107}$ antiwar leafleters were held to have no right to distribute their handbills in a 50-acre privately-owned shopping center. The majority distinguished Amalgamated Food Employees v. Logan Valley Plaza, Inc., ${ }^{108}$ which had accorded a shopping-center the same "public forum" status that Marsh v. Alabama ${ }^{100}$ had given a company town. In Logan Valley, the Lloyd Corp. majority said, the first amendment activity had been "related to the shopping center's operations," since it consisted of union picketing of a supermarket in the center for the purpose of achieving collective bargaining recognition. By contrast, in Lloyd Corp., the antiwar leafleters might as well have distributed their handbills elsewhere. ${ }^{110}$

Lloyd Corp. and Mosley, decided four days apart, thus produce this extraordinary net result: a labor-picketing exception in an ordinance is unconstitutional, but in a "private" shopping center a labor-picketing exception is constitutionally required. The nation deserves better than this, and the first amendment's equality principle demands better.

Some years before the term "public forum" entered the first amendment lexicon, the Supreme Court faced another kind of hid-

is A. Meiklejohn, supra note 25, at 25.

${ }_{106}$ Grayned v. City of Rockford, 408 U.S. 104 (1972). The "material disruption" standard is formulated in Tinker v. Des Moines School Dist., supra note 45, 393 U.S. at 512-14.

${ }^{107} 407$ U.S. 551 (1972).

ins 391 U.S. 308 (1968).

in 326 U.S. 501 (1946).

i1 Cf. Illinois Migrant Council v. Campbell Soup Co., 519 F.2d 391 (7th Cir. 1975) (access to farmworkers living in a residential community operated by employer held governed by Marsh rather than Lloyd Corp.). 
den "classification" produced by legislation that was formally content-neutral. In the late 1950 s, when the civil rights movement was gathering momentum in the South, public disclosure of one's membership in the NAACP typically was followed by annoyances like threats and midnight phone calls, and often by more tangible reprisals like being fired. In a series of cases, the Court held that state and local governments could not constitutionally insist on such disclosure, either by the NAACP itself ${ }^{111}$ or by individual members. ${ }^{112}$

The governments' demands for information in these cases usually were presented for ostensibly neutral purposes. The State of Alabama discovered that it needed the NAACP's membership list in order to determine whether the Association had violated the state's foreign-corporation laws. ${ }^{113}$ The State of Arkansas found it necessary to inquire into the organizational affiliations of its school teachers since some teachers might be spending too much time on outside activities. ${ }^{114}$ The Court, solemnly going along with the gag, took these asserted justifications at face value but concluded nonetheless that the required disclosures unconstitutionally invaded first amendment rights of political association. The Court noted the severity of the private harassment that tended to result from disclosure and held, on the strength of that probable effect, that these facially neutral laws were invalid. ${ }^{115}$

The Court's concern in these cases grows out of the first amendment's equality principle. If all the school teachers in Arkansas were to disclose their respective memberships in organizations, it is a safe bet that most Rotarians and Job's Daughters would not be greeted with heavy breathing when they answered the phone at night. The private harassment that concerned the Court was reserved for those associated with an unpopular challenge to the local orthodoxy. The point here is not simply that first amendment liberties normally matter most to underdogs; it is also that these decisions parallel one

11 Gibson v. Florida Legislative Investigation Comm'n, 372 U.S. 539 (1963); Bates v. City of Little Rock, 361 U.S. 516 (1960); NAACP v. Alabama, 357 U.S. 449 (1958).

112 Shelton v. Tucker, 364 U.S. 479 (1960). See generally H. KaLven, ThE NEgro AND THE First AMENDMENT 65-121 (1965).

113 NAACP v. Alabama, 357 U.S. 449 (1958).

11 Shelton v. Tucker, 364 U.S. 479 (1960).

115 The Court had been far less hospitable to claims of political privacy in earlier cases dealing with the exposure of Communist Party membership. See, e.g., Barenblatt v. United States, 360 U.S. 109 (1959); cf. Communist Party of the United States v. Subversive Activities Control Board, 367 U.S. 1 (1961). We can hope that Harry Kalven was right in predicting that "we may come to see the Negro as winning back for us the freedoms the Communists seemed to have lost for us." H. KALVEN, supra note 112, at 6. 
type of solution to the "state action" problem that historically has plagued efforts to use the equal protection clause to protect individuals against private racial discimination. In the disclosure cases, the state is seen as "encouraging" private discrimination against those who espouse ideas with a particular content, even though the encouragement is embodied in a formally neutral law. ${ }^{116}$

\section{Equality and the Stopping-Place Problem: The Issue of ACCESS TO THE MEdiA}

From the perspective of the first amendment's equality principle, the public forum cases lead us to a far more intractable problem: the issue of a right to access to the press and the broadcast media. No one would seriously argue that picketing and leafleting are as effective as newspapers and broadcasting in communicating messages. ${ }^{117}$ Does the equality principle mean that there is a constitutional right of access not merely to the metaphorical "poor person's printing press" but to the press itself, so that each person's message may be communicated with equal effectiveness?

The first amendment speaks not of access but of freedom. The argument for a first amendment right of access thus appears to place "First Amendment values" ahead of the amendment itself."18 But "equality of status in the field of ideas"119 is not merely a first amendment value; it is the heart of the first amendment. The media-access cases are problematical not because they require a choice between equality and freedom, but because both equality and freedom are to be found on either side of the argument. ${ }^{120}$

In any case, the constitutional values of equality and liberty are fundamentally linked by the notion that equal access to certain

II Cf. Reitman v. Mulkey, 387 U.S. 369 (1967).

117 See Barron, Access to the Press-A New First Amendment Right, 80 Harv. L. Rev. 1641, 1647 (1967). But cf. Jaffe, The Editorial Responsibility of the Broadcaster: Reflections on Fairness and Access, 85 HARv. L. Rev. 768, 769-71 (1972). The point is not so much that the press or the broadcast media convert people, as that they reinforce the conventional wisdom. See Canby, The First Amendment Right to Persuade: Accesq to Radio and Television, 19 U.C.L.A.L. REv. 723, 739-41 (1972).

"1s See Columbia Broadcasting System, Inc. v. Democratic Nat'l Comm., 412 U.S. 94, 145-46 (1973) (Stewart, J., concurring). But see Justice Stewart's approving reference to an opinion's emphasis of "First Amendment values," Jenness v. Fortson, 403 U.S. 431, 437 n.14 (1971).

119 A. MeikLejohn, supra note 25 , at 6 .

120 On the side of the media owners, the equality principle argues against government regulation favoring or disfavoring speech because of its content. A guarantee of access to a medium not only reduces the owner's freedom, but replaces the owner's message with another imposed by the government. On the other side, those who seek access to the media typically invoke the equality principle as a means of exercising their freedom in ways that are effective. 
institutions and services is a prime component of any meaningful liberty. This link is reflected in the language of egalitarian movements. The civil rights movement of the 1960s, for example, marched under the banner of "Freedom" even though its chief objective was equal access-to the vote, to education, to housing, even to lunch counters. "Liberation" is today a theme of more than rhetorical significance in egalitarian causes such as the women's movement. Access and freedom are in no sense antithetical ideas.

Yet the Supreme Court has posed the media-access issue in just such absolutist terms. The Court has recognized the problem created by increasingly centralized private power over the press ${ }^{121}$ and the heretofore inherent limits on the number of licensed broadcasters. ${ }^{122}$ But despite the strong public interest in some guarantee of access, the Court has tended to assume that nothing can be done without abandoning the first amendment principle of freedom from government coercion. When the Court is confronted by a statute guaranteeing access to the press, the admonition of Zechariah Chafee, Jr. is wheeled into position and fired:

Liberty of the press is in peril as soon as the government tries to compel what is to go into a newspaper. ${ }^{123}$

And the FCC's fairness doctrine, according to Justice Douglas,

puts the head of the camel inside the tent and enables administration after administration to toy with TV or radio in order to serve its sordid or its benevolent ends. ${ }^{124}$

It is a familiar argument in the equal protection context that once government imposes an affirmative duty to equalize, such a policy finds no principled "stopping-place," but instead tends to dissolve all the limits by which the Court seeks to contain it. And soon, to use Justice Douglas's metaphor, the whole camel is in the tent. Whenever the Supreme Court extends the affirmative duty of government to protect against inequalities resulting from private

${ }^{12 t}$ See Miami Herald Publishing Co. v. Tornillo, 418 U.S. 241, 248-51 (1974), which held unconstitutional a Florida statute that imposed a "right-to-reply" obligation on newspapers despite the Court's recognition of the tendency toward press monopoly.

12 Columbia Broadcasting System, Inc. v. Democratic Nat'l Comm., 412 U.S. 94, 10102 (opinion of Burger, C.J.). Developments like cable television raise the possibility that the scarcity of broadcast channels may be a passing problem.

123 2 Z. Chafee, Jr., Government and Mass Communications 633 (1947), quoted in Miami Herald Publishing Co. v. Tornillo, 418 U.S. 241, 258 n.24, 261 (1974) (opinions of Burger, C.J. and White, J.).

124 Columbia Broadcasting System, Inc. v. Democratic Nat'l Comm., 412 U.S. 94, 154 (Douglas, J., concurring). 
discrimination, the stopping-place problem is sure to be raised by the dissent. ${ }^{125}$ When the first amendment's equality principle began to generate affirmative-duty issues, it was thus predictable that claims of a constitutional right of access to the media would elicit a similar response: how can any right of access be constructed without turning the communications media into "passive receptacle[s] or conduit[s] for news, comment, and advertising"'? ${ }^{126}$ The principle of equal liberty of expression offers a perspective and a direction for constitutional growth, but does not define its own limits. "Once loosed, the idea of Equality is not easily cabined." 128

Like many equal protection issues, the media-access problem should be approached from two separate constitutional directions. First, what does the Constitution compel government to do in the way of equalizing? Second, what does the Constitution permit government to do in equalizing by statute? The first question is raised by Columbia Broadcasting System, Inc. v. Democratic National Committee $^{129}$ and the second by Red Lion Broadcasting Co. $v$. $F_{C C}{ }^{130}$ and Miami Herald Publishing Co. v. Tornillo. ${ }^{131}$ The stopping-place problem is conceptually much harder in the first type of case, but, as Chafee and the camel remind us, it is also present in the second.

The Supreme Court has relied mainly on two doctrinal devices to contain the affirmative duties imposed by the equal protection clause: the "state action" limitation 132 and a permissive form of "rational basis" judicial review. The CBS case demonstrates that both of these devices are of little help in resolving a constitutional claim of access to the broadcast media.

12s See, e.g., Douglas v. California, 372 U.S. 353, 361-63 (1963) (Harlan, J., dissenting).

124 Miami Herald Publishing Co. v. Tornillo, 418 U.S. 241, 258 (1974).

127 Frank Michelman has proposed a theory of "minimum protection" as a way of resolving the stopping-place problem inherent in claims to equality by persons who cannot afford to pay for various goods and services. Michelman, Foreword: On Protecting the Poor Through the Fourteenth Amendment, The Supreme Court, 1968 Term, 83 HaRv. L. REv. 7 (1969). By analogy, leafleting, picketing, and the like might be regarded as an adequate minimum opportunity to communicate, making access to the press and the broadcast media constitutionally unnecessary. For some of the purposes of freedom of expression, such a minimum protection theory seems sufficient, i.e., self-realization and dignity, the safety valve function, and perhaps even the search for truth. A minimum protection approach to speech seems less helpful, however, in informing the citizenry in a self-governing society.

'23 Cox, Foreword: Constitutional Adjudication and the Promotion of Human Rights,

The Supreme Court, 1965 Term, 80 HaRv. L. REv. 91 (1966).

120 412 U.S. 94 (1973).

130395 U.S. 367 (1969).

13s 418 U.S. 241 (1974).

132 In the context of the due process clause of the fifth amendment, the term "governmental action" is used. 
In $C B S$, the Court held that a licensed broadcaster who satisfies the fairness doctrine ${ }^{133}$ has no constitutional obligation ${ }^{134}$ to sell time for editorial advertisements. The opinion of the Court rested primarily on the first amendment freedoms of the broadcaster. But the Chief Justice and Justices Stewart and Rehnquist also concluded that the conduct of a broadcaster was not subject to any constitutional limit since it did not constitute "governmental action."135 That conclusion, while it has some respectable roots in state action theory, seems quite wrong. Furthermore, it was unnecessary to make this argument at all; the considerations relied on by the Chief Justice seem far more relevant to resolving the constitutional merits.

There are good reasons for concluding that the conduct of a broadcaster is susceptible to some constitutional limitation. A broadcaster is licensed by government not merely to do business, but to use a publicly owned resource. During the period of the license, the broadcaster enjoys a quasi-monopolistic power enforced by government. The broadcaster is subject to detailed and comprehensive regulation of its activities, including the supervision of program content and the obligations imposed by the fairness doctrine. These limitations encourage the very policy choice made by the broadcasters in the $C B S$ case, to refuse editorial advertising. ${ }^{136}$ If a licensed broadcaster had refused to employ black news reporters, there is little doubt that even the three named Justices would have characterized the broadcaster's conduct as governmental action, subject to the Constitution's commands. ${ }^{137}$ What made the differ-

${ }^{133}$ See text at note 147 infra.

134 Nor any obligation under the governing statutes.

135412 U.S. at 119-21. Justice Douglas, who concurred, assumed in a rather strained way that a broadcast licensee's action was not "governmental action." He was troubled by his own previous opinions arguing that other kinds of governmental licensing amount to "state action." 412 U.S. at 149-50; e.g., Moose Lodge No. 107 v. Irvis, 407 U.S. 163, 179 (1972) (dissenting); Garner v. Louisiana, 368 U.S. 157, 183-85 (1961) (concurring).

${ }_{138}$ Not only does the FCC supervise compliance with the fairness doctrine by reviewing licensees' applications for renewal every three years, but it also investigates individual complaints. Furthermore, as the editors of the Harvard Law Review pointed out, the FCC has ruled that licensees must themselves bear the cost of presenting opposing views on controversial issues when paid sponsors are not available; as a result, broadcasters are encouraged to

fill their advertising time with noncontroversial commercial material and thus avoid fairness doctrine responsibilities that might impinge on their programming decisions or reduce their revenues.

Note, The Supreme Court, 1972 Term, 87 HARv. L. REv. 1, 181-82 (1973). The FCC has reduced the impact of the fairness doctrine on paid "commercials," applying it only to those "devoted in an obvious and meaningful way to . . . public issues." 39 Fed. Reg. 26372, 26374; see Public Interest Research Group v. FCC, 522 F.2d 1060 (1st Cir. 1975).

137 This constitutional issue presumably will not arise so long as federal civil rights laws 
ence in $C B S$ for these Justices was the weight of the broadcaster's own constitutional freedom.

If the state action doctrine is to be retained, ${ }^{138}$ the interest of private individuals to act arbitrarily in exercising their own freedoms ought to be considered in deciding whether there is "significant state involvement" in private action. ${ }^{139}$ Although government has no legitimate interest in the freedom to act arbitrarily, an individual does and should be accorded constitutional leeway in some situations in which the state itself would be restricted. A number of state action decisions have properly taken this distinction into account. ${ }^{140}$ But there is another dimension to the state action problem, a dimension unduly minimized by the three Justices in $C B S$ who found no governmental action. A government's action also differs from individual action in its consequences. The action of an individual rarely affects large interests or large numbers of people, but governmental actions typically have broad impact. ${ }^{141} \mathrm{~A}$ licensed broadcaster's connections with government are not mere formalities; governmental policy permeates everything the broadcaster does. The pervasive influence of government policy on the individual broadcaster is wholly in keeping with the notion that the broadcaster performs a function that has a broad societal impact. Absent a delegation of the power to use the public airwaves, government itself might well perform the broadcasting function, as it does in many other countries.

Fortunately, a majority of the CBS Court did not support the proposition that a licensed broadcaster's advertising policy is insufficiently involved with government to justify application of the Constitution to the broadcaster. Two concurring Justices recognized that the Court did not have to distort state action doctrine in order to protect broadcasters. Rather, the Court could give weight to the broadcaster's first amendment freedom in resolving the merits of the would-be advertisers' claimed right to access. Despite the assumptions of Justices Douglas and Stewart, ${ }^{142}$ a finding of govern-

prohibit such racial discrimination in hiring. But the issue seems an easy one.

${ }^{138}$ Cf. Black, Foreword: "State Action," Equal Protection, and California's Proposition 14, The Supreme Court, 1966 Term, 81 Harv. L. Rev. 69 (1967); Horowitz, The Misleading Search for "State Action" Under the Fourteenth Amendment, 30 S. CAL. L. REv. 208 (1957).

13: For the view that this individual interest is not relevant to the question of governmental action, but only to the first amendment claim of the broadcaster, see Note, The Supreme Court, 1972 Term, supra note 136, at 181.

"The theme is developed in some detail in Van Alstyne \& Karst, State Action, 14 Stan.

L. REv. 3 (1961).

"uI Id.

"12 Each wrote a separate concurring opinion. 
mental action does not convert the broadcaster into an agency of the government, or even a public utility; the broadcaster retains some freedom to act arbitrarily in the exercise of its constitutional rights. The state action doctrine may have other problems, but it does not pose an all-or-nothing choice in bringing the Constitution to bear on private conduct.

The state action limitation, then, offers no easy solution to the stopping-place problem presented by a claim of constitutional right of access to the broadcast media. The claim must be assessed on the constitutional merits; and on the merits, constitutional principle does not speak with one voice. On the one hand, the first amendment's equality principle strongly suggests the importance of affording a forum to a diversity of views. ${ }^{143}$ On the other hand, the equality principle also suggests the importance of prohibiting government supervision of the broadcaster's selection from among competing speakers and messages.

In any case, even though the $C B S$ majority followed established practice in placing strong reliance on FCC expertise, the Court's adoption of a "rational basis" standard of review seems misguided under the circumstances. First amendment interests are on both sides of this issue. Just as it is a function of the judiciary to strike the balance between the competing claims of the free exercise clause and the establishment clause of the first amendment, ${ }^{144}$ so it is the courts' responsibility to strike the balance between competing first amendment issues in the media-access cases. The expertise of the FCC does not extend to constitutional interpretation.

The absence of an obvious stopping-place for the claim to access to the broadcast media need not prevent the Supreme Court from drawing any boundary at all. For example, to say that one has a content-neutral right such as the right to have a paid advertisement broadcast within the limits of time set aside by the broad-

16 The recent cases involving press interviews of prisoners can be seen in one dimension as an aspect of the media-access problem. For an explicit reliance in such a context, see Main Road v. Aytch, 522 F.2d 1080 (3d Cir. 1975). For a discussion of the contrast between this "speech" issue and the related "press" issue of the newsperson's right to access to prisoners to gather news, see Nimmer, Introduction-Is Freedom of the Press a Redundancy: What Does It Add to Freedom of Speech?, 26 Hastings L.J. 639, 641-44 (1975); cf. Lange, The Speech and Press Clauses, 23 U.C.L.A.L. REv. 77, 104-06 (1975); Nimmer, Speech and Press: A Brief Reply, 23 U.C.L.A.L. REv. 120, 122-23 (1975). Similarly, Branzburg v. Hayes, 408 U.S. 665 (1972), has a media-access dimension; part of the public's interest in the newsperson's claimed right to keep sources confidential is an interest in having the views of dissidents such as the Black Panthers publicized. Cf. Talley v. California, 362 U.S. 60 (1960).

i' See note 89 supra. 
caster for advertising ${ }^{145}$ in no sense implies that the broadcaster must devote all its time to editorial statements, paid or not. If the principle of the fairness doctrine interferes with the process of setting limits to the media-access claim, ${ }^{146}$ perhaps the fairness doctrine should give way.

It is Red Lion ${ }^{147}$ that is shaky, not the claim of a constitutional right to media-access advanced by the $C B S$ plaintiffs. The fairness doctrine, upheld unanimously ${ }^{148}$ in Red Lion in a right-of-reply situation, is an FCC directive to broadcasters to devote a reasonable amount of time to coverage of public issues and to present contrasting views on these issues. ${ }^{149}$ Any process of continuing governmental surveillance over broadcasting content presents truly grave dangers. If the days of hunting "subversives" in the communications industry seem safely remote, ${ }^{150}$ it is instructive to recall that President Nixon's appointed Chairman of the FCC asked the television networks to furnish him with transcripts of their commentary on the President's speeches. ${ }^{151}$ Even though the right-of-reply portion of the fairness doctrine upheld in Red Lion is less threatening than the doctrine's more general insistence on fair coverage of issues, a right of reply will give added encouragement to an editorial blandness already promoted by the broadcasters' commercial advertisers; ${ }^{152}$ broadcasters will simply minimize the number of newscasts to which a fairness doctrine obligation will attach.

Similar reasoning led the Court in the Tornillo case, ${ }^{153}$ decided one year after $C B S$, to invalidate a Florida right-of-reply statute

is On the implementation of such a right, see Johnson \& Westen, $A$ Twentieth-Century Soapbox: The Right to Purchase Radio and Television Time, 57 VA. L. REv. 574, 626-29 (1971); Canby, supra note 117, at 754-57.

14 See Note, Regulation of Program Content by the FCC, 77 Harv. L. Rev. 701 (1964).

u7 Red Lion Broadcasting Co. v. FCC, 395 U.S. 367 (1969).

is Justice Douglas did not participate in Red Lion. In CBS, he expressed his disagreement with Red Lion, in the passage quoted in text at note 124 supra.

1' See generally Barrow, The Fairness Doctrine: A Double Standard for Electronic and Print Media, 26 Hastings L. J. 659 (1975); Note, Enforcing the Obligation to Present Controversial Issues: The Forgotten Half of the Fairness Doctrine, 10 HaRv. Crv. Rights-Civ. LiB. L. REv. 137 (1975).

${ }^{\text {tso }}$ See Kalven, Broadcasting, Public Policy and the First Amendment, 10 J. LAw \& Econ. 15, 35-37, 45 n.96 (1967).

${ }^{131}$ See Note, supra note 149 , at 157 n.90. Equally instructive is a perusal of the 106 pages devoted by the District of Columbia Circuit to the FCC's abortive attempt to force the NBC television network to present views opposed to those expressed in the documentary, "Pensions: The Broken Promise." Judge Leventhal has the better of these prolonged arguments, from beginning to end. National Broadcasting Co. v. FCC, 516 F.2d 1101 (D.C. Cir. 1974).

${ }^{152}$ On the latter point, see Note, supra note 149 , at 148-50.

135418 U.S. 241 (1974). 
directed at newspapers. The media-monopoly problem is arguably even more serious in the daily press than in the broadcast media. ${ }^{154}$ Yet the Court reacted to the remedy provided by the state ${ }^{155}$ with a burst of first amendment absolutism that is, to put it mildly, uncharacteristic of the present Court:

However much validity may be found in these [access] arguments, at each point the implementation of a remedy such as an enforceable right of access necessarily calls for some mechanism, either governmental or consensual. If it is governmental coercion, this at once brings about a confrontation with [the first amendment]. ${ }^{156}$

Since the Tornillo case could have been resolved by holding the statute under attack to be unconstitutionally vague, ${ }^{157}$ the selection of such a broad ground for decision suggests that the Court was eager to make a more general doctrinal statement. Its choice of language supports this conclusion.

Unfortunately, the more general statement is so sweeping that it is hard to believe the Court could possibly mean what it said. Any governmental compulsion on a newspaper to print what it does not choose to print, said the Court, is unconstitutional. The doctrine, thus stated, would invalidate not only a right-of-reply statute, but also a statute guaranteeing the right to paid advertising space ${ }^{158}$ as well as a statute enabling a defamed plaintiff to compel the defaming newspaper to publish a retraction. ${ }^{159}$ Once again, the Court has

154 But merely to count daily newspapers, radio stations, and television channels is to ignore other branches of the press, from monthly magazines to underground newspapers. For a thoughtful criticism of the arguments in favor of a right of access to the media, see Lange, The Role of the Access Doctrine in the Regulation of the Mass Media: A Critical Review and Assessment, 52 N.C.L. REv. 1 (1973). For Lange's analysis of the statistics of the various media, see id. at 15.

iss It would be inaccurate to describe the statute in Tornillo as a response to a modern problem, since the law dates from 1913. 418 U.S. at 247.

ist 418 U.S. at 254 (footnotes omitted).

${ }^{157}$ The Court did not reach the vagueness question, but the statute was vulnerable on that ground, especially in giving the right of reply whenever a newspaper "assails the personal character" of a candidate or "attacks his official record." FLA. STAT. ANN. § 104.38 (1973).

iss This would be a situation parallel to that in the CBS case, with an FCC rule added to guarantee the advertiser's right, but without the fairness doctrine hanging over the publisher's shoulder. Such statutes have been proposed from time to time. See Note, The Supreme Court, 1973 Term, 88 HARv. L. REv. 41, 180 n.45 (1974). Such a law would not eliminate equal access problems, unless some means could be devised to prevent monopolization of advertising space (or time) by the wealthy.

${ }^{159}$ Justice Brennan, by adding a one-paragraph concurrence, tried to except retraction statutes from the Court's proscription of government compulsion of a newspaper. 418 U.S. at 258-59. 
treated a claim to equality as an all-or-nothing proposition. And, once again, the Court has opted in favor of nothing, despite its lament that economic and technological changes have "place[d] in a few hands the power to inform the American people and shape public opinion."'160

There is a vast and sophisticated literature on the media-access problem, and it would be both silly and arrogant to try to resolve such complex issues in a few pages. ${ }^{161}$ The relevant analogy would be those hourly bursts of news which the fairness doctrine forces into the ears of radio listeners who only want to listen to the "Top 40." Instead, this discussion has aimed at showing some ways in which the first amendment's equality principle may be helpful in approaching the problem, and some ways in which it will provide next to no help at all.

First, the equality principle's prohibition on government control of speech content is of limited use when the problem is one of censorship by private broadcasters and newspapers. The point is not that equality is somehow less desirable when a public forum is privately controlled, but that the equality principle also supports the competing claim of the private censor to freedom from control of speech content. Second, the equality principle suggests that if government surveillance can be minimized and compulsion over the private owners of the media limited to a content-neutral principle, such as a statutory right to paid advertising, then a court should view sympathetically government action to overcome the impact of private censorship. ${ }^{162}$ Third, there is, at least in the broadcasting area, no simple solution to the stopping-place problem in state action doctrine.

Fourth, neither private censorship nor governmental action to alleviate it can properly be tested against the permissive "rational basis" standard of judicial review, since the competing interests in the media-access cases are both of constitutional stature. There is no room for a strong presumption of constitutionality in the $C B S$ situation for either the FCC's rejection of a right to paid advertising time or the broadcaster's own policy of refusing such advertising. Nor is there room in the Tornillo situation for a presumption in

100 Id. at 250.

I6 Lange, supra note 154, at 2 n.5, contains a footnote more than a page long listing articles and other discussions of the media-access problem up to 1973. The literature is still growing.

32 The Court's deference to the FCC in the CBS case suggests that a modification of the faimess doctrine to provide some limited forms of access to the broadcasting media might be upheld, despite the absolutism of the CBS and Tornillo opinions. 
favor of a state right-of-reply law. The judiciary must itself face the difficult task of accommodating competing constitutional interests.

Finally, the media-access problem is not to be dismissed with absolutist abstractions about governmental compulsion. To say that Marsh v. Alabama ${ }^{183}$ is right and Lloyd Corp. v. Tanner ${ }^{164}$ is wrong is to accept and even require restrictions on the freedom of an owner of a company town or a shopping center to censor the content of messages conveyed in those places. Marsh is inconsistent with the absolutist theory, for Marsh imposed restrictions on the owner's first amendment freedoms as well as its property rights. Instead of an absolute prohibition against government-imposed equal access, each proposed claim to access must be addressed in the light of the dynamics of the proposed government intrusion into the particular communications medium and the likelihood of achieving a true diversity of views in the medium. ${ }^{165}$

\section{The First Amendment and "Equal Treatment in THE Voting Process"}

The Constitution nowhere explicity confers a right to vote on anyone. But in 1964, the Supreme Court construed article I, section 2 , of the Constitution to guarantee the right of "qualified" persons

tos 326 U.S. 501 (1946); see text at note 109 supra.

184407 U.S. 551 (1972); see text and note at note 107 supra.

165 Lange, supra note 154 , at $77-89$, presents a powerful argument to the effect that recognition of a right of access to the mass media would, in general, not be likely to result in much of an increase in the diversity of views expressed in the press or over the airwaves. Even if that depressing assessment be true, the argument in the text stands: each medium of communications, and each proposed access right, should be scrutinized separately along the lines suggested. Cf. the view of Jackson, J., concurring in Kovacs v. Cooper, 336 U.S. 77, 97 (1949), that each medium is "a law unto itself."

Consider, for example, a law requiring newspapers to accept paid editorial advertising. The burden on the newspaper's production would be minimal, and more than offset by advertising revenue. The publisher would be commanded by law to publish something it chose not to print. But: (a) the government would not identify subjects worth discussing; that choice would be left to those who seek to advertise; (b) there would be no government supervision to assure "fair" coverage of any issue; (c) there would be no regulation of message content; and (d) the publisher could dissociate itself from any advertising message, both by marginal notations and by editorial statements. The burden on the publisher's freedom, in short, is minimal. Against this burden must be weighed the benefits of such a law in bringing diversity of views to the public. Lange is probably right in suggesting that access laws will not aid the truly deviant, but will produce a new "centrism" dominated by a slightly widened mainstream. Lange, supra note 154, at 81-89. But to say that an excess rule will not do everything (including providing a forum for incitement to riot and revolution) is not to say that it will do nothing. A widened mainstream, with a greater diversity of views for the newspaper's readers, is no small thing. The point is that the absolutism of the Tornillo opinion makes just this sort of interest balancing irrelevant. 
to vote in federal elections. ${ }^{166} \mathrm{~A}$ period of intensive constitutional development had begun. Within the next decade, the Supreme Court came to recognize a constitutional "right to equal treatment in the voting process."167

Although this newly fashioned right has been explained largely as a derivation from the equal protection clause, it rests just as soundly on the first amendment's principle of equal liberty of expression. Indeed, the first amendment demands an even greater degree of equality in the electoral process than does the equal protection clause. The first amendment's equality principle applies both to equality among voters and to equality among candidates and parties.

\section{A. First Amendment Foundations for "the Equal Right to Vote"}

The core of the principle of equal liberty of expression is that government action may not favor or disfavor expression because of its content. Voting is political expression, not simply in the sense of choosing among candidates and policies, but also in the sense of making a statement about the public issues raised during a political campaign. Furthermore, voting is the expression of each voter's claim to the dignity of citizenship. ${ }^{168}$ When the Supreme Court embraced the doctrine of "one person, one vote" in Reynolds $v$. Sims, ${ }^{169}$ it recognized that voter equality was implicit in the idea of "[f]ull and effective participation by all citizens in state government."170 Further, the Court said, quoting itself:

No right is more precious in a free country than that of having a voice in the election of those who make the laws under which, as good citizens, we must live. ${ }^{171}$

The perception of the vote as "voice" is scarcely new, but it captures nicely the first amendment dimensions of the right to vote.

Just two years after Reynolds, the Court heard a challenge to the constitutionality of a poll tax as a condition on voting in a state election, in Harper $v$. Virginia State Board of Elections. ${ }^{172}$ The challenge was based not only on the equal protection clause, but also on the first amendment. Voting was analogized by the appellants to

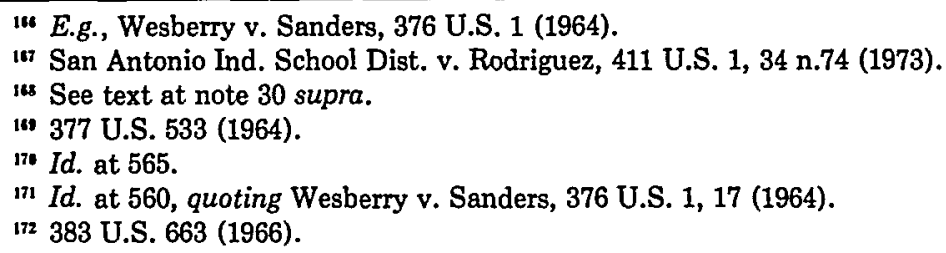


lobbying and to pursuing social or political objectives through litigation, both of which had been held to be forms of first amendment activity. ${ }^{173}$ Furthermore, voting was said to be, like the privacy of political association, necessary to make the first amendment's explicit guarantees effective. ${ }^{174}$ As the Court had previously said: "Other rights, even the most basic, are illusory if the right to vote is undermined." 175

In reversing the three-judge district court's dismissal, the Court did "not stop to canvass the relation between voting and political expression," 176 but held that the poll tax as a condition on voting in state elections was invalid under the equal protection clause. ${ }^{177}$ The Harper opinion set the pattern for a series of decisions striking down various types of voter qualifications such as property ownership ${ }^{178}$ or lengthy residence in the state. ${ }^{179} \mathrm{In}$ San Antonio Independent School District $v$. Rodriguez, ${ }^{180}$ the Court summarized these decisions, all based on the equal protection clause, by saying there was now a constitutional "right to equal treatment in the voting process." 181

Because voting is the most basic act of political expression, the same decisions can be seen as illustrating the equality principle of the first amendment. The poll tax, for example, was defended by Justice Harlan on the ground that the state could rationally conclude:

that people with some property have a deeper stake in community affairs, and are consequently more responsible, more educated, more knowledgeable, more worthy of confidence, than those without means, and that the community and $\mathrm{Na}-$ tion would be better managed if the franchise were restricted to such citizens. ${ }^{182}$

But this result is precisely what the first amendment's equality principle prohibits: a selective restriction on expression, based on

173 NAACP v. Button, 371 U.S. 415, 429-31 (1963) (litigation to pursue social objectives); United States v. Rumely, 345 U.S. 41 (1953) (lobbying).

174 Brief for Apellant at 14-17, Harper v. Virginia Bd. of Elections, 383 U.S. 663 (1966). For the political-association analogy, the brief relied on NAACP v. Alabama, 357 U.S. 449 (1958).

173 Wesberry v. Sanders, 376 U.S. 1, 17 (1964).

3783 U.S. at 665.

17 Id.

${ }^{178}$ E.g., Kramer v. Union Free School Dist. No. 15, 395 U.S. 621 (1969).

17 Dunn v. Blumstein, 405 U.S. 330 (1972).

180411 U.S. 1 (1973).

181 Id. at 34 n.74.

${ }^{182}$ Harper v. Virginia Bd. of Elections, 383 U.S. 663, 685 (1966) (Harlan, J., dissenting). 
the ideas and sentiments likely to be expressed. The "stake in community affairs" of a property owner, as a determinant of a point of view, is an impermissible basis for the state's decision to permit or forbid political expression.

The Court reviewed with approval the property-qualification cases along with the whole line of voting-equality cases when it invalidated a one-year residence requirement for voting in a state election. ${ }^{183}$ Because the law restricted the right to vote, it could be sustained only upon a showing that it was necessary to effect a compelling state interest and that there were no "other, reasonable ways to achieve [the state's] goals with a lesser burden on constitutionally protected activity."184 For this "less drastic means" proposition, the Court cited three first amendment decisions, including the political-privacy case involving the Arkansas teachers. ${ }^{185}$

The voter-qualification cases, seen as first amendment cases, come to this: No citizen can be denied the right to "participate in political affairs or in the selection of public officials"186 unless that denial is necessary to achieve a compelling state interest. Any denial of a voice in the affairs of the political community ${ }^{187}$ demands strict judicial scrutiny because that voice is protected by the first amendment.

Thus far, the first amendment right to vote looks much like the guarantee of equal protection as applied to the "fundamental" interest in voting. ${ }^{188} \mathrm{~A}$ voting qualification based on age, for example, must pass the compelling-state-interest test under either formula. ${ }^{189}$

18s Dunn v. Blumstein, 405 U.S. 330 (1972). Although this case too was decided on equal protection grounds, the Court justified its decision to subject the statute to strict scrutiny in part because it impinged on the opportunity to vote, a right which, as we have seen, also has a first amendment basis.

18 Id. at 343.

iss Shelton v. Tucker, 364 U.S. 479 (1960); see text and note at note 114 supra.

is Kramer v. Union Free School Dist. No. 15, 395 U.S. 621, 626 (1969).

187 The Court relied on this notion of a political community in excluding the rights to vote and hold high office from those to which aliens are presumptively entitled. Sugarman v. Dougall, 413 U.S. 634, 647 (1973). On a similar theory, voting may be limited to residents of a state. Dunn v. Blumstein, 405 U.S. 330, 343-44 (1972). Perhaps a case such as Rosario v. Rockefeller, 410 U.S. 752 (1973), upholding a "no-raiding" law designed to keep members of one political party from switching over to vote in another party's primary, also rests partly on the same theoretical base.

188 At a minimum, the notion of voting as a constitutional right gives doctrinal support to the strict scrutiny which the Court applies, in the name of equal protection, to regulations of the electoral process. See San Antonio Ind. School Dist. v. Rodriguez, 411 U.S. 1, 34 n.74 (1973).

is Justice Stewart, in his separate opinion in Oregon v. Mitchell, 400 U.S. 112, 294 (1970), remarked:

[T]o test the power to establish an age qualification [to vote] by the "compelling 
But recognition of the first amendment right will make a difference where a state disqualifies convicted felons from voting. In Richardson $v$. Ramirez, ${ }^{190}$ the Supreme Court upheld such a disqualification on the strength of section 2 of the fourteenth amendment, which, the Court held, limited the applicability of the equal protection clause. ${ }^{191}$ When considered merely as an equal protection case, the disqualification of ex-felons is thus not required to withstand any judicial scrutiny whatever. But within the framework of the first amendment's equality principle, any disqualification of voters must be justified as necessary to achieve a compelling state interest. For the reasons stated by Justice Marshall in Richardson, no such justification can be found for disqualifying ex-felons from voting. ${ }^{192}$

Nor will literacy tests survive the first amendment right to equality in voting-assuming, that is, that they ever return from the

interest" standard is really to deny a State any choice at all, because no State could demonstrate a "compelling interest" in drawing the line with respect to age at one point rather than another.

Similarly, Justice Rehnquist complained of Justice Stewart's "irrebuttable presumptions" doctrine as announced in Cleveland Bd. of Educ. v. LaFleur, 414 U.S. 632 (1974):

Nothing in the Court's opinion clearly demonstrates why its logic would not equally well sustain a challenge . . . from a 17-year-old who insists that he is just as well informed for voting purposes as an 18-year-old . . . .

414 U.S. at 658 (Rehnquist, J., dissenting). Indeed, age discrimination does seem a good candidate for one of the stricter forms of judicial scrutiny. The point has relevance for the first amendment as well as the equal protection clause, despite the abstractness of a case like Ginsberg v. New York, 390 U.S. 629 (1968). See Letwin, Regulation of Underground Newspapers on Public School Campuses in California, 22 U.C.L.A.L. REv. 141, 187-205 (1974), criticizing the usual arguments for assuming away the first amendment rights of children.

The point is not that 17-year-olds, or 16-year-olds, must be allowed to vote. The point is that both the first amendment and the equal protection clause demand strict scrutiny of any denial of the right to vote. Since no one has yet effectively explained what qualities voters are supposed to have, apart from a concern for their own interests, Justice Stewart is correct in saying it would be hard to justify any particular age limit as necessary to achieve a compelling state interest.

One very important by-product of a claim to equality is that it compels a reexamination of the reasons someone is not treated equally. Perhaps 17-year-olds should vote, if we cannot think of any very good reason for disqualifying them. More likely, however, the courts will find that the state legislatures have discerned an age of maturity-or, alternatively, that the twenty-sixth amendment, in setting the age of 18 as a constitutional maximum, has impliedly authorized the setting of 18 as a minimum. Cf. Richardson v. Ramirez, 418 U.S. 24, 41-56 (1974), upholding the denial of the vote to ex-felons on a similar textual argument.

190418 U.S. 24 (1974).

19 Section 2 provides for the reduction of representation in Congress of any state that denies the vote to male citizens over 21 "except for participation in rebellion, or other crime." It would not be impossible for the present Court to conclude that the same provision impliedly limits the reach of the first amendment; it would merely be silly.

102418 U.S. at 77-86. 
limbo to which Congress sent them in $1970 .{ }^{193}$ A literacy qualification is related not to maturity of judgment, but to the capacity to be informed through the particular mode of the printed word. In an era when 95 percent of the homes in the country have television sets, turned on for an average of more than five hours a day, ${ }^{194}$ the ability to read a newspaper is scarcely required for an understanding of public affairs. More important, many of the illiterate belong to impoverished racial and ethnic minorities; and even to the extent they do not, the illiterate are apt to share significant interests and opinions with those who are disadvantaged in other ways, such as the poor. It is hard to resist the conclusion that literacy tests, like property qualifications and poll taxes, have been used to limit the vote to those who can be counted on to be "responsible"-in other words, to vote according to a particular cluster of ideologies. The first amendment's equality principle forbids such a limitation on the voice embodied in the right to vote.

The first amendment's equality principle also casts new light on the Court's apportionment cases. One of the best-known passages of Chief Justice Warren's opinion in Reynolds $v$. Sims is his comment:

Legislators represent people, not trees or acres. Legislators are elected by voters, not farms or cities or economic interests. ${ }^{195}$

In dissent, Justice Harlan argued that it would be

more meaningful to note that people are not ciphers and that legislators can represent their electors only by speaking for their interests-economic, social, political-many of which do reflect the place where the electors live. ${ }^{196}$

Of course legislators represent people by representing interests. But the holding of Reynolds $v$. Sims is that a state cannot constitutionally discriminate among voters by giving some interests greater proportional weight than is justified by the numbers of people who share those interests.

The first amendment's principle of equal liberty of expression

"ss The 1970 Voting Rights Act, upheld in this respect in Oregon v. Mitchell, 400 U.S. 112 (1970), forbade the use of literacy tests for voting for a five-year period. In 1975, this prohibition was made a permanent part of the Act, and the Act itself was extended for seven years. Act of Aug. 6, 1975, Pub. L. No. 94-73, § 102, 89 Stat. 400, 42 U.S.C.A. $\$ 1973 b$ (Supp. $5,1975)$.

"' N. Johnson, How To Talk Back To Your Television Set 13 (1970).

is 377 U.S. at 562.

13 Id. at 623-24 (Harlan, J., dissenting). 
demands the same conclusion. Just as the hours available in a public forum may not be weighted according to the content of a message, because the first amendment protects speakers as well as ideas, ${ }^{197}$ political expression by voting may not be weighted according to the content of a vote. Justice Harlan's view is, in a sense, a claim that each interest is entitled to "access" to the legislative halls. But not even the most zealous advocate of a right of access to the media would propose that government set aside a weighted number of a newspaper's columns to assure that a particular point of view be satisfactorily represented. ${ }^{198}$

For the most part, the first amendment's equality principle will produce results in apportionment cases similar to those reached under the equal protection clause. But in some cases, application of a rigorous first amendment analysis will reveal the weaknesses of the equal protection decisions. The Court's recent tolerance for the "de minimis" variations in state-legislative-district equality, ${ }^{199}$ for example, is questionable when viewed against the first amendment. And its acceptance of "supermajorities" 200 is a plain violation of the first amendment's equality principle. A two-thirds vote requirement for the passage of a ballot proposition is the clearest example of content discrimination: a "No" vote equals two "Yes" votes. ${ }^{201}$ In Gordon $v$. Lance, the Court impliedly reaffirmed that a weighting of votes that results in discrimination against a "discrete and insular minority," such as a racial group, would be invalid under the equal protection clause. ${ }^{202}$ The first amendment's equality principle is not so limited, but extends to discrimination against any expression on the basis of its content, regardless of the nature of the disfavored group.

Racial gerrymandering is unconstitutional under either an equal protection (or fifteenth amendment) approach or the principle of equal liberty of expression. But the first amendment provides another reason to abandon the untenable distinction between

197 See text at notes 99-100 supra.

193 The fairness doctrine, see text at note 147 supra, seems constitutionally suspect because it does something very much like this.

199 See White v. Regester, 412 U.S. 755 (1973); Gaffney v. Cummings, 412 U.S. 735 (1973).

200 Gordon v. Lance, 403 U.S. 1 (1971).

201 In the case of supermajority requirements, it is not unreasonable to suppose that the exercise of the right of expression of those who intend to vote for the proposition for which a supermajority is required will be chilled by the futility of attempts to overcome this content discrimination.

${ }^{202} 403$ U.S. at 5. 
Southern racial gerrymanders, which are usually held invalid, ${ }^{203}$ and Northern racial gerrymanders, which are valid unless proved to be invidiously motivated. ${ }^{204}$ Finally, political gerrymandering, which the present Court seems prepared to accept under equal protection analysis, ${ }^{205}$ is vulnerable to the first amendment equality principle because it presents an obvious discrimination by government against political expression on the basis of its content. ${ }^{206}$

The "equal right to vote," 207 as announced in the Court's opinions to date, is a right based on the equal protection clause. But, as Justice Brennan recently said, it is also a first amendment right. ${ }^{208}$

\section{B. The Equality Principle and Access to the Ballot for Candidates and Parties}

If the first amendment principle of equal liberty of expression underlies the right to vote, then it unquestionably underlies the rights of those seeking a place on the election ballot, the supreme political forum. It must, in short, guarantee a place on the ballot to anyone who meets the qualifications of the office in question ${ }^{209}$ unless the exclusion of that person is necessary to achieve a compelling state interest. The Supreme Court has relied on both the equal protection clause and the first amendment in reaching this result.

This dual doctrinal approach was first used in Williams $v$. Rhodes, ${ }^{210}$ where the Court invalidated a state law limiting access

200 E.g., Gomillion v. Lightfoot, 364 U.S. 339 (1960). But cf. Dallas County v. Reese, 95 S. Ct. 1706 (1975). See also Sims v. Amos, 336 F. Supp. 924 (M.D. Ala.), aff'd, 409 U.S. 942 (1972).

204 Whitcomb v. Chavis, 403 U.S. 124 (1971); Wright v. Rockefeller, 376 U.S. 52 (1964). This North-South division is criticized in Karst, Not One Law at Rome and Another at Athens: The Fourteenth Amendment in Nationwide Application, 1972 WASH. U.L.Q. 383, $397-404$.

${ }^{203}$ See, e.g., Gaffney v. Cummings, 412 U.S. 735 (1973).

204 "Racial and ethnic gerrymandering are subcategories of political gerrymandering; their ultimate purpose is always political." Comment, Political Gerrymandering: A Statutory Compactness Standard as an Antidote for Judicial Impotence, 41 U. CH. L. REv. 398 n.5 (1974). The kind of statutory standard suggested in the quoted comment would not seem to be beyond a court's capacities as a constitutional standard. Most impotence, we now know, is psychological.

${ }^{207}$ Evans v. Cornman, 398 U.S. 419, 426 (1970). said:

${ }^{208}$ In his dissenting opinion in Storer v. Brown, 415 U.S. 724, 756 (1974), Justice Brennan

The right to vote derives from the right of association that is at the core of the First Amendment .....

200 These qualifications are themselves subject to examination under both the equal protection clause and the first amendment. For an equal protection analysis, see Developments in the Law-Elections, 88 HARv. L. REv, 1111, 1217-33 (1975) (excellent student treatment of election law beyond the franchise) [hereinafter cited as Developments].

${ }^{210} 393$ U.S. 23 (1968). 
to the general-election ballot to candidates nominated by "established" parties-those that had obtained at least 10 percent of the votes in the last gubernatorial election-or by any party able to secure signatures on nominating petitions equal to 15 percent of those who voted in the last election. ${ }^{211}$ Justice Black's opinion for the Court discussed both the first amendment freedom of political association and the equal protection clause, but based the decision on the latter, applying a strict-scrutiny standard of review. ${ }^{212}$

Strict scrutiny was called for because two fundamental interests, the right to vote ${ }^{213}$ and the freedom of political association, were restricted by the state's system. The Court then rejected the state's claim that the promotion of a two-party system was a compelling interest:

The fact is, however, that the Ohio system does not merely favor a "two-party system"; it favors two particular partiesthe Republicans and the Democrats-and in effect tends to give them a complete monopoly. There is, of course, no reason why two parties should retain a permanent monopoly on the right to have people vote for or against them. Competition in ideas and governmental policies is at the core of our electoral process and of the First Amendment freedoms. ${ }^{214}$

Like the Mosley opinion, the opinion in Williams $v$. Rhodes rests its decision on the equal protection clause only after demonstrating that the crucial constitutional interests at stake are first amendment interests.

The Court has made frequent use of the Williams rationale in cases involving both minority parties and independent candidates. After some initial confusion, the Court has refined that rationale to what may be stated as a general principle: A state may constitutionally insist that a candidate or a party have "significant support" before being placed on the ballot, but any system of restrictions

211 The petitions had to be submitted nine months before the election.

${ }^{212}$ Latent in the Court's opinion, as a basis for strict-scrutiny review under the equal protection clause, is the notion of a first amendment right to vote. See note 188 supra. Justice Douglas concurred in the opinion of the Court, but wrote separately to emphasize the first amendment ground for decision. 393 U.S. at 35. Justice Harlan concurred solely on the basis of the first amendment. 393 U.S. at 41.

${ }^{213}$ Even under the challenged statute, no voter was disqualified from voting in the general election; by giving a constitutional dimension to the interest in voting for a particular party or candidate, the Court underlined the expressive aspects of voting, and thus the first amendment interest in the franchise. This view of the right to vote is reaffirmed in the filingfee case of Lubin v. Panish, 415 U.S. 709, 713-14 (1974).

24393 U.S. at 32. 
must permit a "reasonably diligent" candidate or party to qualify. ${ }^{215}$ The Court continues to scrutinize strictly the way in which a state regulates access to the ballot; in order to pass muster under both the first amendment and the equal protection clause, the restrictions must be "essential to serve a compelling state interest." 216

Since sightings of compelling interests have been rarer than sightings of abominable snowmen, that test sounds formidable, especially in view of the plain availability of less burdensome means of achieving the particular state interest. Nonetheless, in the most recent ballot-access cases, the Court has found certain interests to be compelling: the avoidance of the voter confusion resulting from a long ballot and "preservation of the integrity of the electoral process." 217 The latter phrase appears to refer primarily to the avoidance of "frivolous or fraudulent candidacies." 218 The Court has been criticized for not characterizing yet another state interest as "compelling": the interest in preserving a two-party system to avoid excessive factionalism and promote stability. ${ }^{219}$ Testing these three ostensibly compelling interests against the first amendment's equality principle reveals that one sighting is false, and the others open to question.

A plausible explanation for the Court's reluctance to treat the preservation of the two-party system as a compelling interest is that this interest is flatly inconsistent with the first amendment's guarantee of equal liberty of expression. To score the easy point first, there is no analytic force to the distinction drawn by Justice Black in his majority opinion in Williams $v$. Rhodes, between preserving a two-party system and preserving the current two-party system. ${ }^{220}$ Maintaining the dominance of the Democratic and Republican parties in the political market is a patently impermissible state goal because it strikes at the heart of the first amendment's guarantee of "equality of status in the field of ideas." ${ }^{21}$ The same reasoning would hold even if a two-party system somehow could be main-

215 Storer v. Brown, 415 U.S. 724, 738-40 (1974); American Party v. White, 415 U.S. 767 (1974); see Developments 1139-44.

216 Storer v. Brown, note 215 supra, 415 U.S. 724, 729 (1974). The Supreme Court of California has recently applied the compelling state interest test to a city charter provision requiring the listing of incumbents first on city election ballots. The court held the provision invalid under the equal protection clause and the analogous clauses of the state constitution. Gould v. Grubb, 14 Cal. 3d. 661, 122 Cal. Rptr. 377, 536 P.2d 1337 (1975).

${ }^{217}$ American Party v. White, 415 U.S. 767, 782 n.14 (1974).

218 Jenness v. Fortson, 403 U.S. 431, 442 (1971).

219 Developments 1138-39, 1141-42.

220393 U.S. at 31-32. This point is made in Developments at 1138.

221 A. MEIKLEjohN, supra note 25, at 27. 
tained without preserving the existing duopoly. Surely a state could not demonstrate that this means of chilling the expression of minority political viewpoints was necessary to effect a compelling state purpose.

Although minority parties and independent candidates rarely win major elections, their role in influencing the major parties is well known. Moreover, the public's post-Watergate distrust of traditional politicians promises even greater success for minority parties in the future. ${ }^{222}$ It seems certain that fear of minority party gains prompted Republicans and Democrats in state legislatures around the country to enact these ballot-access restrictions in the first place.

The situation is thus an ideal opportunity for application of Chief Justice Stone's famous footnote suggesting "searching judicial inquiry" into legislation that "tends seriously to curtail the operation of those political processes ordinarily to be relied upon to protect minorities." ${ }_{223}$ Even if minority parties and independent candidates always lost and never managed to influence the major parties, the equality principle of the first amendment would forbid excluding them in order to promote parties with different philosophies. The view that favors "a politics of coalition and accommodation"224 over fragmentation is itself a political ideology the state is forbidden to favor. ${ }^{225}$

If preserving the two-party system is an illegitimate state interest, only the two interests actually suggested by the Court remain for serious consideration. By analogy to the "no-raiding" rules upheld by the Court, ${ }^{226}$ the interest in avoiding fraudulent candidacies seems legitimate. If three Jane Smiths enter an election to distract the voters from one particular Jane Smith, the state has good reason to worry about the health of the democratic process, although there

222 In 1974, an independent candidate was elected Governor of Maine. On the role of minority parties and independent candidates, see Developments 1123.

223 United States v. Carolene Products Co., 304 U.S. 144, 152 n.4 (1938).

224 A. Bickel, REForm and Continuity 22 (1971), quoted in Developments at 1138.

${ }^{225}$ But cf. Storer v. Brown, 415 U.S. 724, 736 (1974), recognizing the legitimacy of protecting the state's "interest in the stability of its political system" against "splintered parties and unrestrained factionalism." That interest may survive scrutiny under the equal protection clause, but the first amendment's equality principle makes it illegitimate as a justification of discriminating against offering minority political positions to the electorate.

${ }^{223}$ Rosario v. Rockefeller, 410 U.S. 752 (1973). In Rosario, the Court rejected an attack on a New York statute that imposed a lengthy enrollment requirement for voting in party primaries. The statute's justifiable purpose was 'to inhibit party 'raiding,' whereby voters in sympathy with one party designate themselves as voters of another party so as to influence or determine the results of the other party's primary." Id. at 760. 
appears to be no cure for this particular abuse that would be constitutional.

There is another kind of fraudulent candidacy that may arouse the state's concern. When a member of one party seeks to run in another party's primary, it seems equally sensible to seek to prevent that candidacy. ${ }^{27}$ Although preventive measures would interfere with the would-be candidate's equal right of political association, the alternative would be to ignore the state's interest in avoiding subversion of the primary by deceiving the party's members, itself an interest of first amendment dimension. ${ }^{228}$

The issue is nevertheless troublesome. The first amendment requires an assumption that the best judges of deception in political expression are the people. Censorship of political speech is impermissible even if the speech is false. Why not trust independents, for example, to find out for themselves that a candidate who purports to be independent was, in fact, until last week a member of the Democratic Party - and in voting to give that fact whatever weight they think it deserves? Should government decide when a candidacy is "frivolous"? More important, how should such a determination be made?

The same sort of question can be asked about the voter confusion that, it is often assumed, might result from having a large number of candidates on the ballot. At some point, the concern takes on substance-say, if the voters are handed a list of a thousand names and told to "vote for seven." But even here the assumption that the voters need the state's guidance in making their selections is dangerously paternalistic. Moreover, it seems doubtful that liberalizing the requirements for ballot access would typically trigger a great proliferation of candidates; is there really a compelling state interest in having only four candidates for governor on the ballot rather than eight?

The existing doctrines governing ballot-access cases are still so general that a fair number of such cases should continue to come to the Court. As the Court applies these broad doctrines to a variety of legislative and factual settings, the questions raised here will become increasingly prominent. The most encouraging feature of the newest decisions in this area is their insistence on particularized exploration of the question whether minority parties and independent candidates have a "real and essentially equal opportunity for

227 Thirty states require some form of party affiliation. See Developments 1175-76.

22x Cf. note 187 supra, discussing the relevance of the concept of a "political community." 
ballot qualification." ${ }^{229}$

The role of the first amendment's equality principle in the electoral process should not be limited to the ballot access and voterequality cases. The principle finds easy application to the candidate-filing-fee cases, ${ }^{230}$ and to such qualifications for office as property ownership. ${ }^{231}$ Durational residence requirements for candidates present a harder question, but surely not, as has been suggested, ${ }^{232}$ because strict scrutiny is inappropriate.

The thorniest issues for the equality principle in the elections field are those raised by the regulation of campaign financing. ${ }^{233}$ These widespread laws are motivated by egalitarian goals of the highest order, such as preventing the buying of office or governmental favors. Yet at least some of the laws involve what can only be called discrimination based on speech content. Prohibitions against corporations' or unions' making political contributions, for example, raise the gravest problems of selective content censorship. ${ }^{234}$ Here, as in the media-access cases, the courts are only beginning to explore the limits of what the first amendment will allow, and what it may demand. Like the media-access cases, any campaign-finance regulation calls for particularized balancing of the benefits it may provide by increasing diversity of political expression against its

299 American Party v. White, 415 U.S. 767, 788 (1974).

${ }^{200}$ Lubin v. Panish, 415 U.S. 709 (1974); Bullock v. Carter, 405 U.S. 134 (1972). In their first amendment aspects, the poll-tax and property-qualification cases readily support these recent fling-fee decisions, see text and notes at notes 172-82 supra. See Justice Douglas's concurring opinion in Lubin v. Panish, supra at 719-22.

231 The approval in Developments at 1220-21 of a rational basis standard of review for such qualifications for office is unjustified in view of the first amendment interest at stake. Furthermore, since such qualifications infringe the right to vote, see note 213 supra, strict scrutiny is required under the equal protection clause.

In any case, a property qualification for holding office fails even the rational basis test. See Developments at 1221-23. The Court so held in Turner v. Fouche, 396 U.S. 346, 361-64 (1970), seemingly giving "rational basis" the tougher meaning it has been given in a number of decisions in the past five years. See generally Gunther, Foreword: In Search of Evolving Doctrine on a Changing Court: A Model for a Newer Equal Protection, The Supreme Court, 1971 Term, 86 HaRv. L. REv. 1 (1972).

${ }^{232}$ Developments 1227 . The point would be that a reasonable durational residence qualification for office arguably serves a compelling state interest by providing officials with some experience in the community. Given the first amendment interests of the would-be candidate, however, this is a difficult issue. Cf. Note, The Right to Vote in Municipal Annexations, 88 HaRv. L. REv. 1571, 1574-79 (1975).

${ }^{233}$ See generally Fleishman, Freedom of Speech and Equality of Political Opportunity: The Constitutionality of the Federal Election Campaign Act of 1971, 51 N.C.L. REv. 389 (1973); Developments 1237-71, and the many discussions there cited.

zas See Comment, The Constitutionality of the Federal Ban on Corporate and Union Campaign Contributions and Expenditures, 42 U. CHI. L. REv. 148, 161-65 (1974). 
costs to political freedom. ${ }^{235}$ No slogan-not even Equality-can substitute for such an inquiry.

\section{The Equality Principle as a Preferred Ground}

Late last term, the Supreme Court decided one of those cases destined to go into the constitutional law casebooks only as a footnote. In Erznoznik v. City of Jacksonville, ${ }^{236}$ the Court invalidated a city ordinance prohibiting drive-in movie theaters from showing films, visible from public streets, that included nudity. The city had sought to justify the ordinance on three grounds: protection of the privacy of citizens against unwilling exposure to offensive material; protection of children; and protection against traffic hazards. Erznoznik is noteworthy for the repeated emphasis in Justice Powell's opinion for the Court on the equality principle of the first amendment.

In response to the privacy argument, the Court admitted that regulation of speech might sometimes be appropriate to protect privacy. But, said Justice Powell:

[W] hen the government, acting as censor, undertakes selectively to shield the public from some kinds of speech on the ground that they are more offensive than others, the First Amendment strictly limits its power. See, e.g., Police Department of Chicago v. Mosley. . . . 237

Only an "intolerable" invasion of a "substantial" privacy interest, the Court reasoned, would justify repression; ${ }^{238}$ here the passer-by who was offended could simply look away.

Second, in response to the protection-of-children argument, the Court relied on the ground that the ordinance's restriction was "broader than permissible," since in banning all nudity it was not tailored to an identified state interest. ${ }^{239}$ Third, the ordinance,

zos Whatever may be the constitutional fate of campaign spending limitations and disclosure requirements in general, the latter should not survive close judicial scrutiny when they are applied to minor parties. Donors who are asked to contribute to unpopular causes may refuse to do so if they face exposure. The political privacy cases discussed in the text at notes 111-16 supra are very much in point. See Judge Bazelon's opinion, dissenting in part, in Buckley v. Valeo, 519 F.2d 821, 907 (D.C. Cir.), prob. juris. noted, 96 S. Ct. 32 (1975), for a careful analysis of the issue. Judge Bazelon notes that the effect of disclosure on donations to minor parties is a form of content discrimination, invalid under Mosley. 519 F.2d at 909 n.14.

236 95 S. Ct. 2268 (1975).

237 Id. at 2272.

238 Id. at 2273 (quoting from Cohen v. California, 403 U.S. 15, 21 (1971)).

23 Id. at 2274 . 
viewed as a traffic regulation, also violated the equality principle:

By singling out movies containing even the most fleeting and innocent glimpses of nudity the legislative classification is strikingly underinclusive. There is no reason to think that a wide variety of other scenes in the customary screen diet, ranging from soap opera to violence, would be any less distracting to the passing motorist.

This Court frequently has upheld underinclusive classifications on the sound theory that a legislature may deal with one part of a problem without addressing all of it. . . . This presumption of statutory validity, however, has less force when a classification turns on the subject matter of expression. "[A]bove all else, the First Amendment means that government has no power to restrict expression because of its message, its ideas, its subject matter, or its content." Police Dept. of Chicago v. Mosley . . . . Thus, "under the Equal Protection Clause, not to mention the First Amendment itself," . . . even a traffic regulation cannot discriminate on the basis of content unless there are clear reasons for the distinctions. See also Cox v. Louisiana . . . (opinion of Black, J.). Cf. Williams v. Rhodes ....$^{240}$

The Erznoznik opinion is in no sense unusual. The citation and quotation of Mosley is becoming commonplace as a shorthand for the first amendment's principle of equal liberty of expression. ${ }^{241}$ And the equality principle is becoming a preferred ground for decision. ${ }^{242}$ The reasons are easy to see. The principle permits the Court to protect first amendment activity without making a frontal attack

${ }^{210}$ Id. at 2275-76. Justice Douglas, concurring, agreed that the ordinance was "fatally overinclusive in some respects and fatally underinclusive in others." Id. at 2277.

${ }_{211}$ E.g., San Antonio Ind. School Dist. v. Rodriguez, 411 U.S. 1, 16, 34 (1973); id., 411 U.S. at 61 (Stewart, J., concurring); Columbia Broadcasting System v. Democratic National Committee, 412 U.S. 94, 129-130 (1973); id., 412 U.S. at 39 (Stewart, J., concurring); Lehman v. City of Shaker Heights, 418 U.S. 303 (1974); id., 418 U.S. at 311 (Brennan, J., dissenting); American Mini Theatres, Inc. v. Gribbs, 518 F.2d 1014, 1020 (6th Cir.), cert. granted, 96 S.Ct. 214 (1975); Aiona v. Pai, 516 F.2d 892, 893 (9th Cir. 1975); Gay Students Organization v. Bonner, 509 F.2d 652, 661 (1st Cir. 1974).

${ }_{212}$ An interesting parallel development is the application of 42 U.S.C. § 1985(3), which provides for damages for conspiratorial deprivations of equal protection, to first amendment interests. In Glasson v. City of Louisville, 518 F.2d 899 (6th Cir. 1975), the court held that section 1985(3) reached the conduct of a police officer who took a poster from a woman and destroyed it, because it was, in his view, "detrimental to the President," who was passing by. But cf. Greenwood v. Peacock, 384 U.S. 808 (1966), holding that 28 U.S.C. $\S 1443(1)$, providing for removal of state-court proceedings to a federal court where one is denied "equal civil rights," does not include first amendment rights in the quoted phrase. 
on the legitimacy of the interest by which the state seeks to justify its regulation. Deciding, for example, that a particular statute is invalid because it is not narrowly tailored to the state's interest does not prohibit the state from attempting to further the same interest by other means. Analyzing a first amendment case within the framework of the equality principle thus may encourage the Court to be somewhat more interventionist in making doctrine. Furthermore, the idea of equal treatment has a special emotional appeal, not only to the Justices, but to the Court's varied constituencies, including the public.

There are additional reasons for believing that the equality principle will turn out to be more protective of speech than previously-established first amendment doctrines. As Justice Jackson saw in Railway Express, ${ }^{243}$ using an equal protection analysis to invalidate legislation will force legislators to face the question of whether they want to impose a particular regulation on everyone. It is simply not true that the automatic legislative reaction will be to do just that. ${ }^{244}$ Harry Kalven, as always, is instructive on the point:

Everyone at some time or other loves a parade whatever its effect on traffic and other uses of public streets. Municipalities pressed by concern with the protest movement may be inhibited in any rush to flat nondiscriminatory prohibitions by the difficulty of distinguishing between the parades we like and others. Equal protection may, therefore, require freedom for the parades we hate. ${ }^{245}$

Finally, the equality principle is apt to protect speech because it places an affirmative burden on those who would justify a restriction on expression to demonstrate that it is necessary to achieve a compelling state interest. The recent development of stricter forms of judicial scrutiny under the equal protection clause cannot fail to influence the courts as they examine first amendment interests in the light of the equality principle. Just as the principle of equality permits a court to engage in a narrower, more focused form of intervention into the legislative process, so the equality principle requires particularized inquiry into the state's asserted reasons for limiting speech.

It would have been extraordinary if the egalitarian impulses of

${ }^{213}$ See text at note 23 supra.

24' It is so argued in Note, supra note 7, at 476-77.

215 Kalven, supra note 41 , at 30. 
the past generation had not made a significant impact on first amendment decisions and theory. In this area of constitutional law, as throughout American society, claims to equality have demanded a critical re-examination of fundamental principles. As a result, the essential principles of a system of free expression now emerge in sharper relief. At the heart of that system, part of the "central meaning" of the first amendment, is the guarantee of equal liberty of expression. 